\title{
Article \\ Proteomic Changes during the Dermal Toxicity Induced by Nemopilema nomurai Jellyfish Venom in HaCaT Human Keratinocyte
}

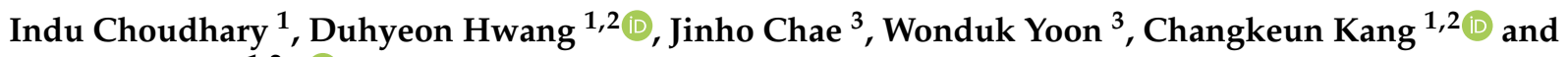 \\ Euikyung Kim 1,2,*(D) \\ 1 College of Veterinary Medicine, Gyeongsang National University, Jinju 52828, Korea; \\ induchoudhary2u@gmail.com (I.C.); pooh9922@hanmail.net (D.H.); ckkang@gnu.ac.kr (C.K.) \\ 2 Institute of Animal Medicine, Gyeongsang National University, Jinju 52828, Korea \\ 3 Marine Environmental Research and Information Laboratory, B1101, 17 Gosan-ro 148beon-gil, \\ Gunpo-si 15850, Gyeonggi-do, Korea; jinhochae@gmail.com (J.C.); wondukyoon@humer.co.kr (W.Y.) \\ * Correspondence: ekim@gnu.ac.kr; Tel.: +82-55-772-2355; Fax: +82-55-772-2349
}

Citation: Choudhary, I.; Hwang, D.; Chae, J.; Yoon, W.; Kang, C.; Kim, E. Proteomic Changes during the Dermal Toxicity Induced by Nemopilema nomurai Jellyfish Venom in HaCaT Human Keratinocyte. Toxins 2021, 13, 311. https://doi.org/ 10.3390/toxins 13050311

Received: 16 March 2021

Accepted: 20 April 2021

Published: 27 April 2021

Publisher's Note: MDPI stays neutral with regard to jurisdictional claims in published maps and institutional affiliations.

Copyright: (c) 2021 by the authors. Licensee MDPI, Basel, Switzerland. This article is an open access article distributed under the terms and conditions of the Creative Commons Attribution (CC BY) license (https:// creativecommons.org/licenses/by/ $4.0 /)$.

\begin{abstract}
Jellyfish venom is well known for its local skin toxicities and various lethal accidents. The main symptoms of local jellyfish envenomation include skin lesions, burning, prickling, stinging pain, red, brown, or purplish tracks on the skin, itching, and swelling, leading to dermonecrosis and scar formation. However, the molecular mechanism behind the action of jellyfish venom on human skin cells is rarely understood. In the present study, we have treated the human HaCaT keratinocyte with Nemopilema nomurai jellyfish venom (NnV) to study detailed mechanisms of actions behind the skin symptoms after jellyfish envenomation. Using two-dimensional gel electrophoresis (2-DE) and matrix-assisted laser desorption-ionization time-of-flight mass spectrometry (MALDI-TOF/MS), cellular changes at proteome level were examined. The treatment of $\mathrm{NnV}$ resulted in the decrease of $\mathrm{HaCaT}$ cell viability in a concentration-dependent manner. Using $\mathrm{NnV}$ (at $\mathrm{IC}_{50}$ ), the proteome level alterations were determined at $12 \mathrm{~h}$ and $24 \mathrm{~h}$ after the venom treatment. Briefly, 70 protein spots with significant quantitative changes were picked from the gels for MALDI-TOF/MS. In total, 44 differentially abundant proteins were successfully identified, among which 19 proteins were increased, whereas 25 proteins were decreased in the abundance levels comparing with their respective control spots. DAPs involved in cell survival and development (e.g., Plasminogen, Vinculin, EMILIN-1, Basonuclin2, Focal adhesion kinase 1, FAM83B, Peroxisome proliferator-activated receptor-gamma co-activator 1-alpha) decreased their expression, whereas stress or immune response-related proteins (e.g., Toll-like receptor 4, Aminopeptidase N, MKL/Myocardin-like protein 1, hypoxia up-regulated protein 1, Heat shock protein $105 \mathrm{kDa}$, Ephrin type-A receptor 1, with some protease (or peptidase) enzymes) were up-regulated. In conclusion, the present findings may exhibit some possible key players during skin damage and suggest therapeutic strategies for preventing jellyfish envenomation.
\end{abstract}

Keywords: Nemopilema nomurai jellyfish; 2-DE; MALDI-TOF/MS; HaCaT cell; dermal toxicity

Key Contribution: This is the first report revealing the dermal molecular changes at proteomic level induced by jellyfish venom, which may lead us to understand the pathogenesis and hopefully suggest an idea of interrupting the dermal poisoning symptoms.

\section{Introduction}

Mainly the jellyfish number has expeditiously proliferated in current years; thus, jellyfish envenomation cases shoot up. According to the National Institutes of Health (NIH), 150 million people were accidentally injured by jellyfish every year. The jellyfish Nemopilema nomurai from phylum cnidaria is around $2 \mathrm{~m}$ in diameter and $200 \mathrm{~kg}$ body 
weight, is one of the giant jellyfish in the world [1]. It has special stinging cells (nematocysts) attached to several thread-like tentacles. $\mathrm{NnV}$ is the fusion of complex components abundant in peptides and proteins, many bioactive proteins having a cytotoxic, hemolytic, hepatotoxic, cardiotoxic activity, or neurotoxic components reside inside hollow tubules in the nematocysts [2-5]. A significant difference in jellyfish venom compositions between different species was noticed based on their geographical locations, as well as seasonal variations [4].

The cnidarian nematocysts are of various sizes and shapes, produced by special cells called nematocytes, and they are bulb-shaped capsules containing a coiled, hollow, usually barbed thread that forcefully eject outward upon stimulation [6]. Cnidocils are hair-like sensory processes projecting from a cnidoblast's surface, believed to trigger the discharge of the nematocyst [7]. During contact with human skin or prey, jellyfish tentacles release thousands of toxin-enriched nematocysts into the skin through the shaft, injecting their venomous components simultaneously. Mostly, swelling and itching are the everyday observations in the affected skin area, but sometimes in severe cases, it can cause skin necrosis [8]. Moreover, histamine is released due to the exocytosis of mast cells by jellyfish venom [9]. Jellyfish stings can also result in many systemic symptoms such as neurological gastrointestinal, cardiac, or allergic responses after entering the general circulation [10]. Ventricular arrhythmias and cardiac arrest due to jellyfish venom in severe cases may lead to mortalities [11-13]. Acute renal failure was also observed due to intravascular hemolysis by jellyfish envenomation [12]. The box jellyfish Chironex fleckeri is the most venomous marine creature, and its envenomation can cause cardiorespiratory distress and leads to death within few minutes [14,15]. Jellyfish Chironex fleckeri toxins can induce edema, vesicle formation, erythema, result in extensive progression of necrosis and cause purple to brown wounds [14-16]. The everlasting serious impediment of such wounds consists of granulomas, hyperpigmentation, fat atrophy, and keloids [15,16].

Dermal toxicity is prevalent in response to venom from different organisms, and the mode of action is the same. Earlier it was demonstrated that snake venom protease could cause edema, hemorrhagic activity, inflammatory response, and necrosis in injured skin [17]. N. annulifera snake venom contains multiple components responsible for local and systemic inflammatory reactions, disrupt the human coagulation system, cause lung hemorrhage, ultimately leads to death, and venom is cytotoxic human keratinocytes [17-19]. It was demonstrated earlier that sea urchin envenomation could cause mast cell degranulation, disruption of cell metabolism, cause frequent pain, bleeding, edema, dermatitis, cardiovascular collapse, and respiratory failure [20].

Previously, it was reported that American scorpion Didymocentrus krausi result in thrombotic effect and fibrinogenolytic activity in vivo and in vitro animal models [21]. An earlier study suggested that Palythoa zoanthid corals and Ostreopsis dinoflagellates-derived toxin named palytoxin (PLTX) had caused deleterious effects on human health [22]. PLTX exposure resulted in severe dermatological distress during Ostreopsis blooms; hence PLTX triggers the cytotoxic effects in vitro [22]. Our former investigation has shown that the metalloproteinase present in the scyphozoan jellyfish venom predominately mediates dermal toxicity $[23,24]$. However, the mechanism of dermal toxicity involving $\mathrm{NnV}$ effects remain unexplored. $\mathrm{NnV}$ is the fusion of complex components abundant in peptides and proteins, which are discharged after proper provocation [25].

Our recent proteomics studies revealed that Nemopilema nomurai venom contains various novel components such as phospholipase D Li Sic Tox beta IDI, a serine protease, putative Kunitz-type serine protease inhibitor, phospholipase A2, disintegrin and metalloproteinase, leukotoxin, hemolysin, three-finger toxin MALT0044C, allergens, venom prothrombin activator trocarin D, tripeptide Gsp 9.1, and many other toxin proteins [25]. Moreover, other transcriptomics, genomics, and proteomics studies have recognized numerous classes of toxins from $\mathrm{NnV}$, comprising metalloprotease, hemolysin, cytotoxins, c-type lectin, potassium channel inhibitor, g channel-forming toxins, thrombin, and many others $[14,15]$. Hence have a fatal role in the lethality caused by $\mathrm{NnV}$ stinging. 
Such components may contribute to venom toxicity and leads to the deleterious effect of venom on human health. The molecular mechanism behind the jellyfish's envenomation on human skin cells is still unidentified. In the current research, we have revealed Nemopilema nomurai jellyfish venom's critical targets in human skin cells using HaCaT model keratinocytes.

\section{Results}

\subsection{NnV Induces Cytotoxicity in HaCaT Cell Lines}

The dermal toxicity effect of $\mathrm{NnV}$ on HaCaT cells was analyzed using MTT (3-(4,5dimethyl-2-yl)-2,5-diphenyltetrazolium bromide) assay. In short, cumulative concentrations $(0-5 \mu \mathrm{g} / \mathrm{mL})$ of $\mathrm{NnV}$ were used to treat the HaCaT cells for $24 \mathrm{~h}$. Cells without $\mathrm{NnV}$ treatment were considered control, $\mathrm{NnV}$ treatment reduced the growth of HaCaT cells in a concentration- and time-dependent manner (Figure 1). On treatment with the lower concentrations $(0.5$ and $0.8 \mu \mathrm{g} / \mathrm{mL})$ of $\mathrm{NnV}$ there was no substantial change observed in cell viability after $24 \mathrm{~h}$ of treatment. While with 1,3 , and $5 \mu \mathrm{g} / \mathrm{mL} \mathrm{NnV}$, Cell growth was reduced to $57.3 \%, 47.1 \%$, and $35.4 \%$, respectively. The cell viability was significantly reduced after treatment with $3 \mu \mathrm{g} / \mathrm{mL}$ of $\mathrm{NnV}$ for $24 \mathrm{~h}$ in comparison to the control cells. Probit analysis was used to determine the IC50 value of NnV concentration $(2.5 \mu \mathrm{g} / \mathrm{mL})$; at this concentration, a 50\% reduction in cell proliferation was observed. Further, the number of viable cells was significantly decreased after $\mathrm{NnV}$ treatment in a concentration- and timedependent manner and $\mathrm{NnV}$ had antiproliferative activity. The IC50 value $(2.5 \mu \mathrm{g} / \mathrm{mL})$ of $\mathrm{NnV}$ was used for treating $\mathrm{HaCaT}$ cells for proteomic analysis. The morphological characteristics of HaCaT cells were analyzed under the phase-contrast microscopic (Figure 2). In the present study, we have evaluated that $\mathrm{NnV}$ displayed cytotoxic effects in $\mathrm{HaCaT}$ cells at different periods ( $12 \mathrm{~h}$ and $24 \mathrm{~h}$ ). Compared to the control, the NnV treated cells showed loss of adhesion with round shape, shrinking diameter, necrosis, and development of apoptotic fragments and decreased percentage of viable cells (Figure 2). Cell viability was rapidly decreased in $12 \mathrm{~h}$, and $24 \mathrm{~h} \mathrm{NnV}$ treated HaCaT cells compared to untreated control cells. $\mathrm{NnV}$ treated HaCaT cells after $24 \mathrm{~h}$ showed a significant decrease in cell viability as compared to $12 \mathrm{~h}$ treated cells. In contrast, $\mathrm{HaCaT}$ control cells shown average growth. DAPI staining assay was performed to determine the effect of $\mathrm{NnV}$ on apoptosis, nuclear morphological change in treated HaCaT cells (Figure 3). It was observed that percentage of viable cells decreased in $12 \mathrm{~h}$ and $24 \mathrm{~h} \mathrm{NnV}$ treated HaCaT cells. Cell necrosis and nuclear morphological changes were noticed in venom treated HaCaT cells after $12 \mathrm{~h}$ and $24 \mathrm{~h}$. 


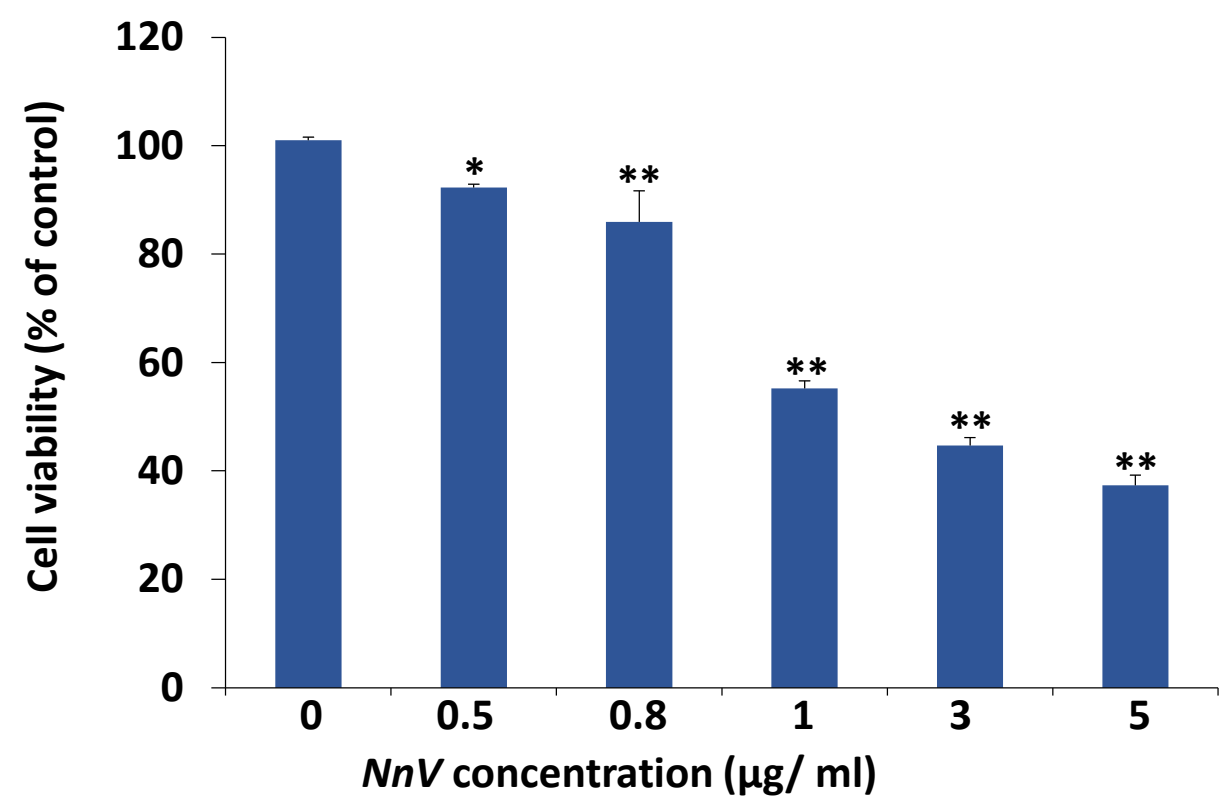

Figure 1. The proliferation of HaCaT human keratinocytes was inhibited by Nemopilema nomurai jellyfish venom (NnV). HaCaT cells were exposed to different concentrations of $\mathrm{NnV}$ for $24 \mathrm{~h}$, and the 3-(4,5-dimethyl-2-yl)-2,5-diphenyltetrazolium bromide (MTT) Assay was performed to analyze the cell viability. Bar graphs represent the mean $\pm \mathrm{SD}$ of three independent experiments. The * asterisk specifies a statistically significant difference in comparison to control ${ }^{*} p<0.05,{ }^{* *} p<0.01$.

A

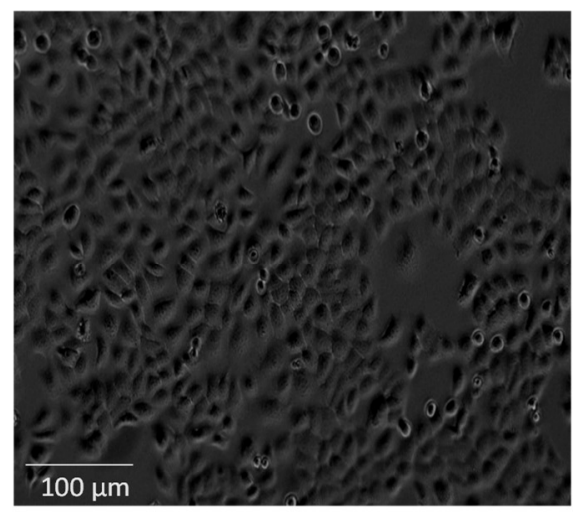

Control
B

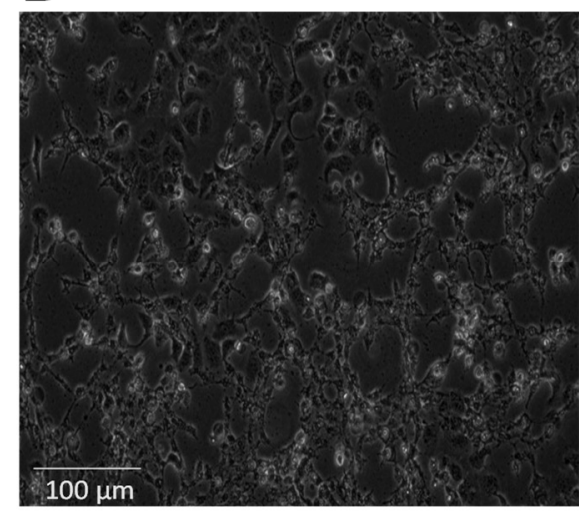

$12 \mathrm{~h}$

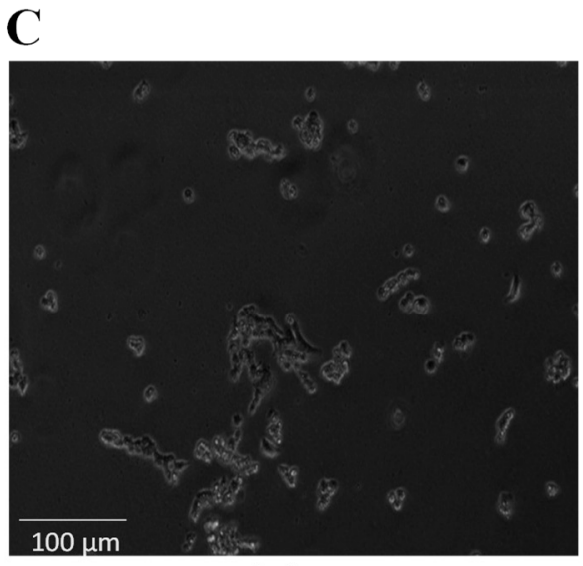

24 h

Figure 2. Morphological changes in HaCaT cells exposed to N. nomurai jellyfish venom. Treatment with N. nomurai jellyfish venom at a concentration of $2.5 \mu \mathrm{g} / \mathrm{mL}$ for $0 \mathrm{~h}(\mathbf{A}), 12 \mathrm{~h}(\mathbf{B})$, and $24 \mathrm{~h}(\mathbf{C})$. The morphological changes were analyzed under a phase-contrast microscope. Cell viabilities were rapidly decreased in HaCaT cells treated with $\mathrm{NnV}$ for $12 \mathrm{~h}$ and $24 \mathrm{~h}$ compared to untreated control cells. 


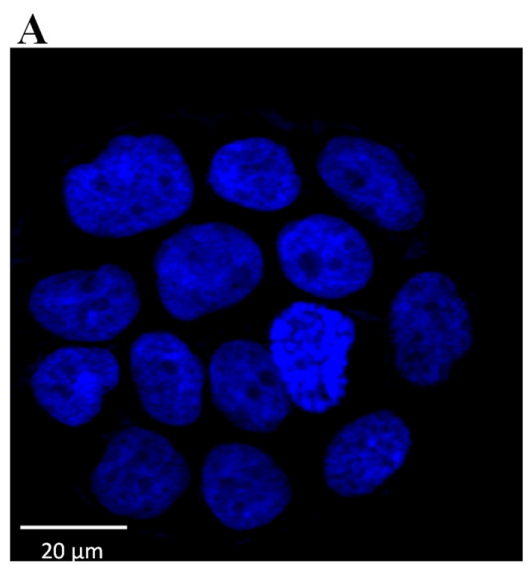

Control

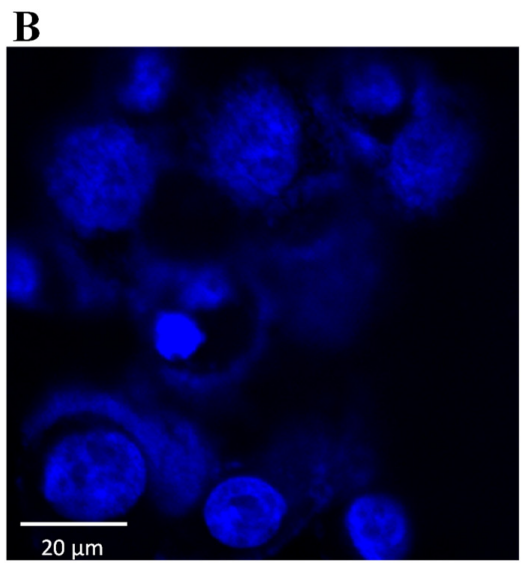

$12 \mathrm{~h}$

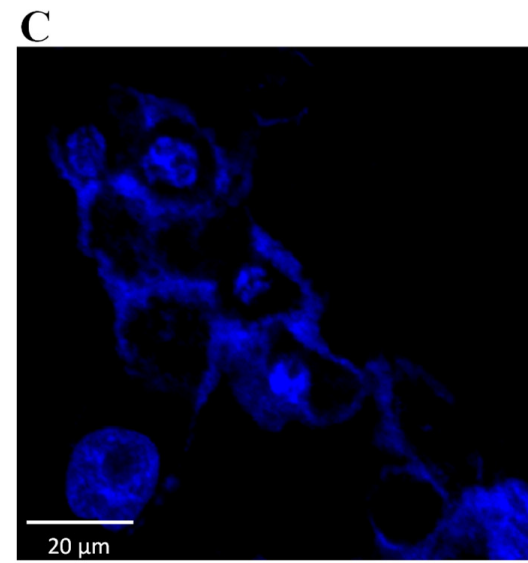

$24 \mathrm{~h}$

Figure 3. Nuclear staining by DAPI of human HaCaT cells exposed to N. nomurai jellyfish venom. HaCaT cells were treated with $N$. nomurai jellyfish venom for $0 \mathrm{~h}(\mathbf{A}), 12 \mathrm{~h}(\mathbf{B})$, and $24 \mathrm{~h}$ (C). Various morphological changes were seen in the HaCaT cells exposed to $\mathrm{NnV}$, including apoptosis, nuclear condensation, and formation of the apoptotic bodies. The Images shown are representative pictures photographed during the experiment using a fluorescence microscope.

\subsection{Two-Dimensional Gel Electrophoresis of Cellular Proteins from NnV-Treated HaCaT Cells}

To explore the proteomic changes in $\mathrm{HaCaT}$ cells with and without $\mathrm{NnV}$ treatment, we performed the relative proteomic study. The protein level variations between non-treated and $\mathrm{NnV}$ treated $\mathrm{HaCaT}$ at IC50 for 12 or $24 \mathrm{~h}$ were assessed by 2-DE. Three independent biological replicates and corresponding gels were run for the analysis from each treatment. After silver staining, around 1000 protein spots were visible. All three gels from the three independent experiments for each treatment showed similar patterns of 2-DE protein spots supporting the reproducibility of our experiment. Figure 4 shows the representative 2-DE images of protein isolated from non-treated and $\mathrm{NnV}$-treated (12 h and $24 \mathrm{~h}$ ) $\mathrm{HaCaT}$ cells. After scanning all 2-DE gels, Progenesis Same software (Nonlinear Dynamics, New Castle, UK) was used to analyze the images. Seventy differentially abundant protein spots with more than a 1.5-fold change in intensity and statistical significance (ANOVA $p$-value_0.05) were picked after automatic spot detection and image analysis. The 2-DE gel image was generated after fusing the control's images, and $\mathrm{NnV}$ treated samples (12 h and $24 \mathrm{~h}$ ) (Figure 5). MALDI/TOF/MS analysis was performed to determine these 70 differentially abundant proteins.

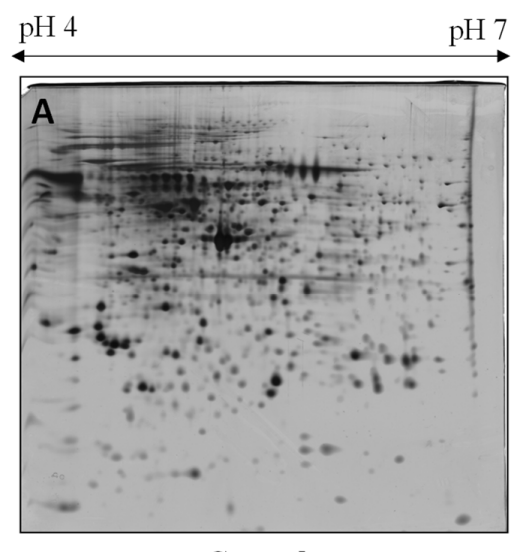

Control
$\mathrm{pH} 4$

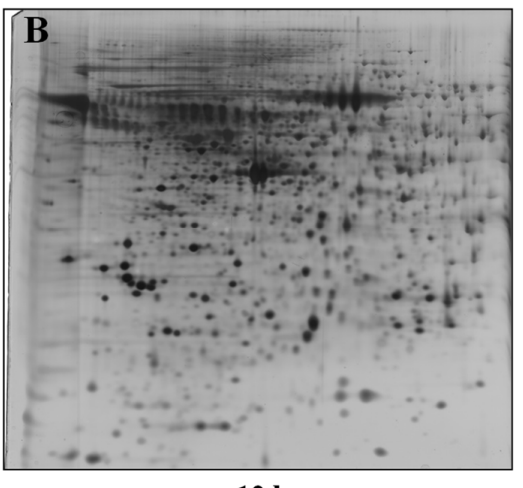

$12 \mathrm{~h}$
$\mathrm{pH} 7 \mathrm{pH} 4$

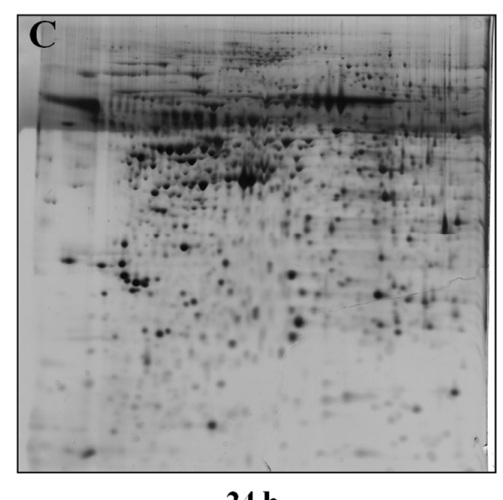

Figure 4. Proteomic comparison of 2-DE images of HaCaT cells treated with $\mathrm{NnV}(2.5 \mu \mathrm{g} / \mathrm{mL})$ for $0 \mathrm{~h}(\mathbf{A}), 12 \mathrm{~h}(\mathbf{B})$, and $24 \mathrm{~h}$ (C). A total of $300 \mu \mathrm{g}$ protein was resolved on $18 \mathrm{~cm}$ IPG dry strips ( $\mathrm{pH} 4-7 \mathrm{~L}$ ) for the first dimension. Then, 12\% SDS-PAGE gels were used for the second dimension. The 2-DE gels were silver stained and scanned by Epson perfection V 700 photo scanner to assess each spot's protein amount. Three independent experiments for each treatment were carried out to run three 2-DE gels for each treatment. 


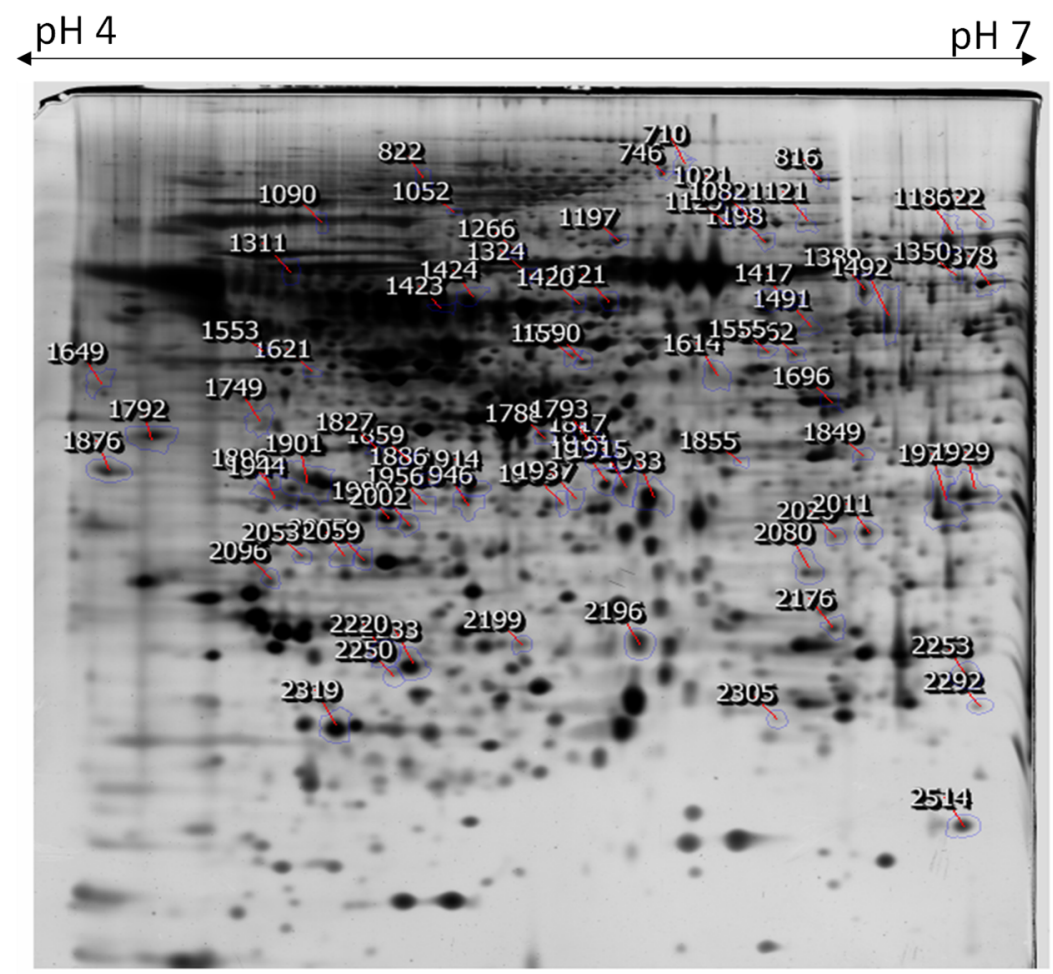

Figure 5. Image showing proteomic analysis of 2-DE of $N n V$ treated HaCaT cells. Representative 2D image was generated using Progenesis Same Spots software, and MALDI-TOF/MS was used to analyze the protein spots. The position of differentially abundant proteins were marked with boundaries and arrows.

\subsection{Ontological Classification of Differentially Abundant Proteins}

Based on the gene ontology classification, the 44 identified proteins which were significantly increased or decreased in $\mathrm{NnV}$ treated $\mathrm{HaCaT}$ cells were further classified based on the molecular function, biological process, protein class, and cellular component of the molecules (Figure 6). Based on molecular component ontology, the proteins' two main functional categories are binding $(43.30 \%)$ and catalytic activity $(26.70 \%)$. Some proteins exhibited molecular function regulator $(13.30 \%)$, transporter activity, and transcription regulator activity $(6.70 \%)$. Most proteins were associated with biological regulation $(23.1 \%)$, cellular component organization or biogenesis $(17.9 \%)$, metabolic process $(15.4 \%)$, developmental process and cellular process $(10.30 \%)$, biological adhesion and localization $(5.10 \%)$, and multicellular organismal process $(2.60 \%)$ based on their biological processes. Later these proteins were classified based upon functional protein classes; the dominant class is of transcription factor and enzyme modulator $(22.7 \%)$; the second abundant class is hydrolase $(18.20 \%)$. Several proteins share these categories: cytoskeletal protein $(9.1 \%)$, transporter, transfer/carrier protein, transferase, nucleic acid binding, and calcium-binding protein $(4.50 \%)$, as shown in the figure. In terms of cellular components, the majority of these proteins were localized in cell and organelle $(32.3 \%)$, membrane $(16.10 \%)$, protein-containing complex $(9.70 \%$, cell junction, and synapse $(3.2 \%)$, as shown in Figure 6 . Identified proteins belong to vital signaling pathways like apoptosis signaling pathway, histamine H1 receptor-mediated signaling pathway, angiogenesis, Alzheimer disease-amyloid secretase pathway, Integrin signaling pathway, alpha-adrenergic receptor signaling pathway, inflammation mediated by chemokine and cytokine signaling pathway, endothelin signaling pathway, EGF receptor signaling pathway, gonadotropin-releasing hormone receptor pathway, thyrotropin-releasing hormone receptor signaling pathway, oxytocin receptormediated signaling pathway and blood coagulation shown in Figure 7. 

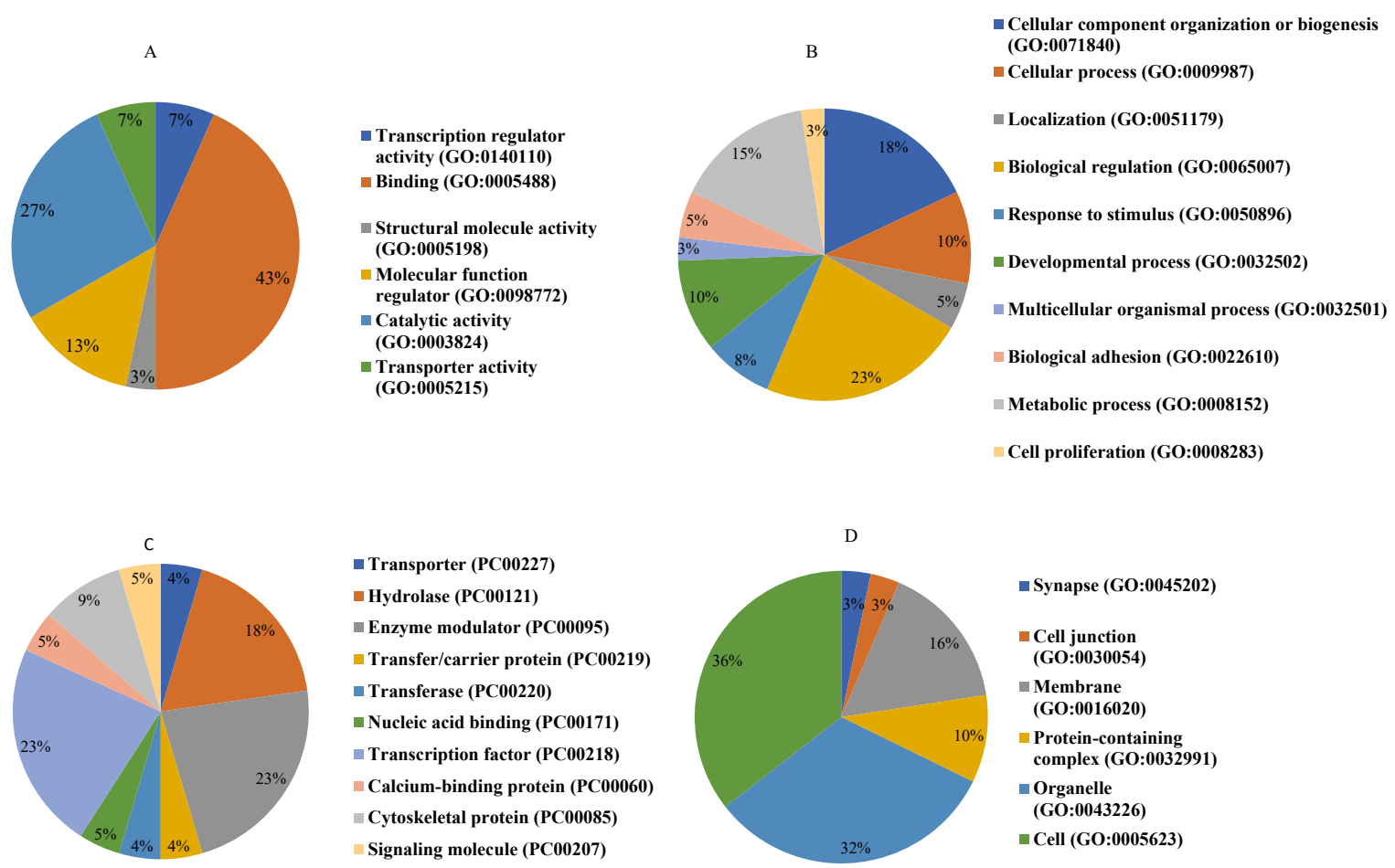

Figure 6. Gene ontology (GO) classification of identified proteins. The proteins were characterized into four groups based on (A), molecular function (B), biological process (C), protein class (D), and cellular component. The Panther classification system was used for GO analysis [http:www.pantherdb.org/ (accessed on 3 January 2019)].
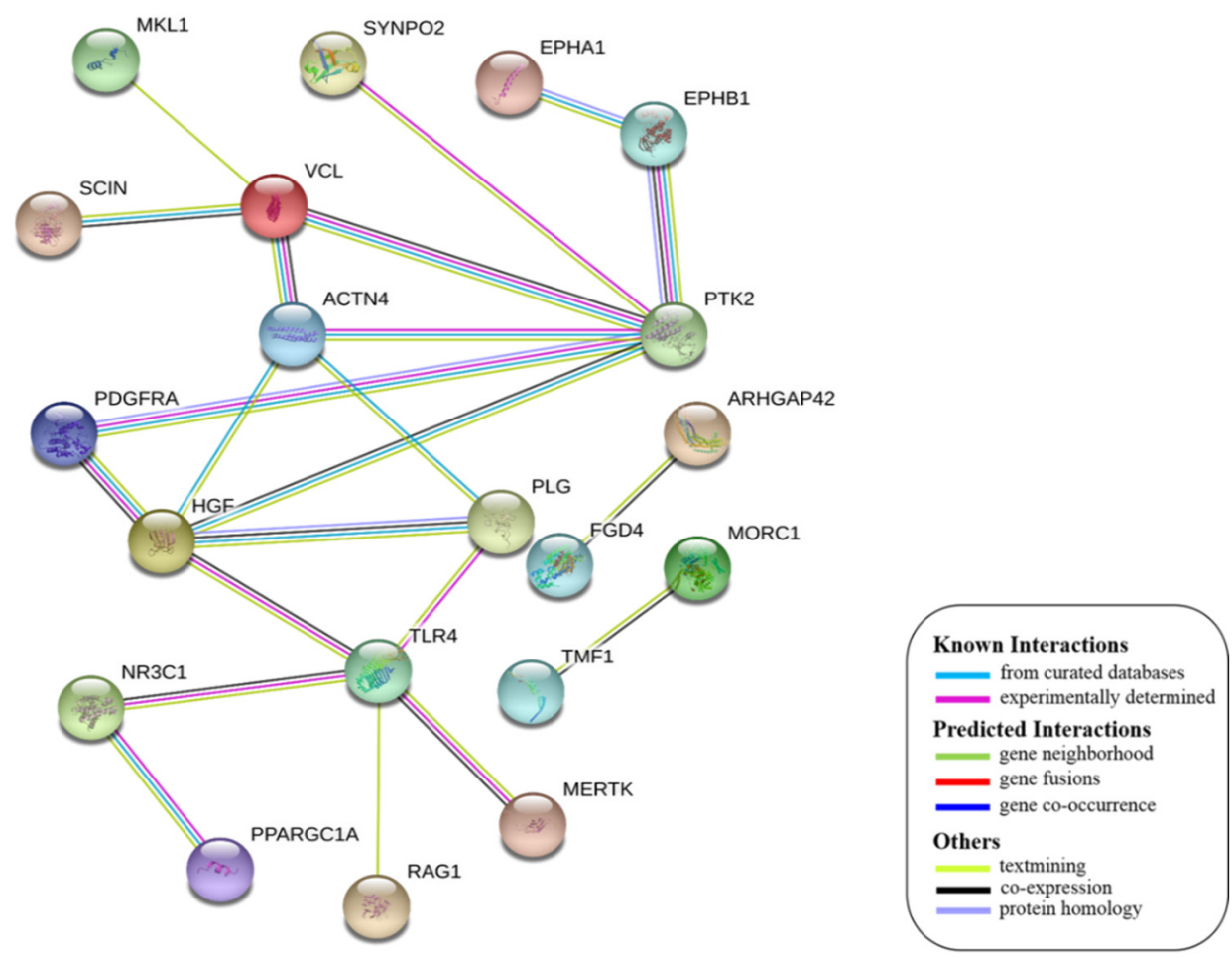

Figure 7. A putative interaction network of known proteins with altered protein amounts using STRING database V 10.5 (http:/ / string-db.org (accessed on 3 January 2019). The basis of interactions is signified by different colored lines, as shown on the right panel. 


\subsection{Protein-Protein Interactions}

String interactions illustrate protein-protein interactions among the up and downregulated proteins, as shown in Figure 7. Most of the proteins were classified into three distinct groups. All the groups were interconnected with each other. The first group consists of focal adhesion kinase (PTK2), vinculin (VCL), which is involved in cell-matrix adhesion, cell proliferation, cell spreading maintain cell morphology and locomotion. VCL is present in the middle of the group, displays interaction with other essential proteins such as $\alpha$-Actinin- 4 and PTK2. The bioinformatic analysis suggested that Toll-like receptor 4 participated as an essential key player with plasminogen (PLG) and glucocorticoid receptors (NR3C1), which plays a crucial function in epidermal development, cell migration, proliferation, and wound healing. The KEGG (Kyoto Encyclopedia of Genes and Genomes) pathway and the string interactions for individual proteins are shown in Table 1.

Table 1. The string network interactions of differentially proteins in NnV treated HaCaT cells along with KEGG pathways.

\begin{tabular}{cccc}
\hline S. No & Protein Name & KEGG Pathways \\
\hline Elastin microfibril interface \\
located protein 1 \\
(EMILIN-1)
\end{tabular}

Glucocorticoid

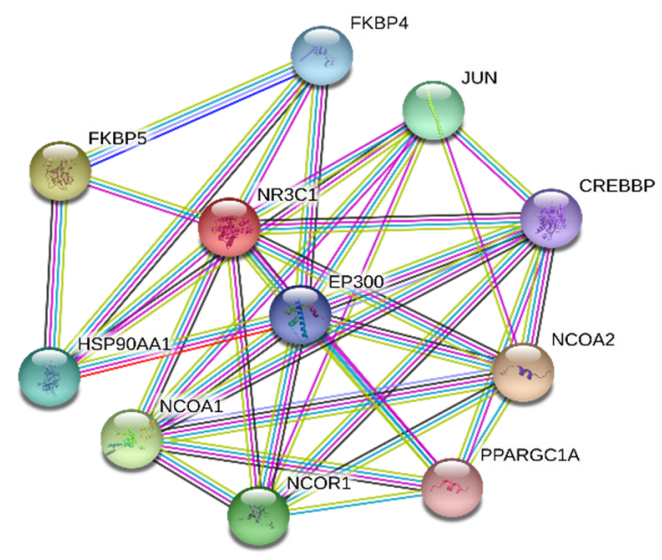

HIF signaling pathway, Thyroid hormone signaling pathway
Plasminogen

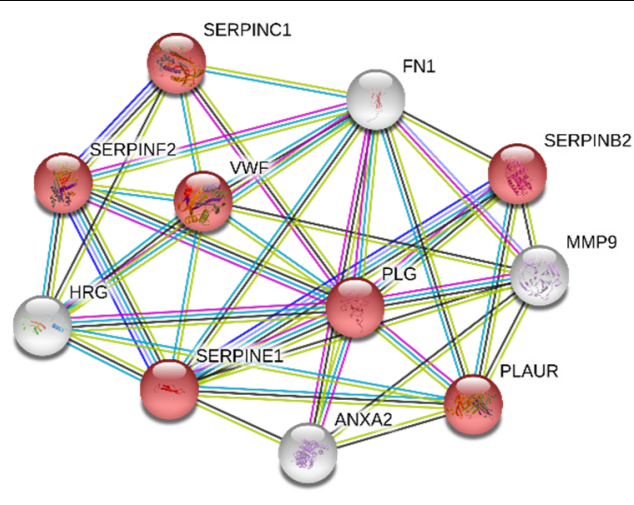

Complement and coagulation cascades 
Table 1. Cont.

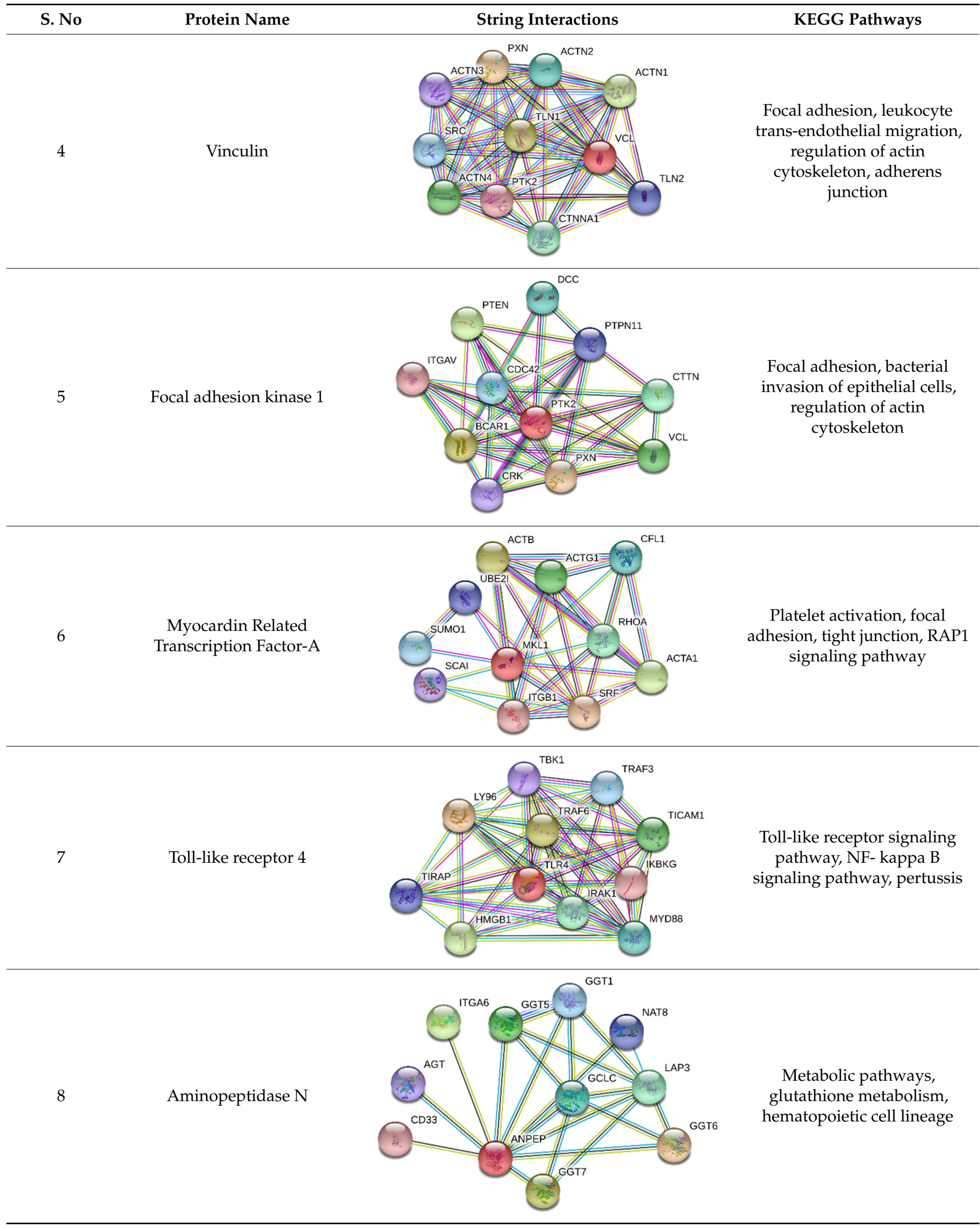


Table 1. Cont.

\begin{tabular}{cccc}
\hline S. No & Protein Name & KEGG Pathways \\
DNA replication \\
licensing factor MCM2
\end{tabular}

\section{Discussion}

In the coastal areas, jellyfish envenomation cases are on the rise worldwide. According to the National Institutes of Health (NIH), around 150 million people accidentally get injured by jellyfish every year [1]. Jellyfish envenomation can induce local consequences such as erythematous eruption, flaring sensations, edema, and necrosis and generate critical systematic symptoms including cardiovascular discomfort, respiratory impairment and hypovolemic attack [2-5]. From our prior findings, we have found that most of the scyphozoan jellyfish venoms are rich in metalloproteinase ingredients, which have a vital role in the pathogenesis of damaged skin tissue in an in vivo model [23,24]. The jellyfish Nemopilema nomurai induce life-threatening effects in human beings and cause many deleterious effects [2]. Our earlier proteomics analysis provides an overall complete understanding of the $\mathrm{NnV}$ components, which are described above [25]. Many investigators have examined dermal toxicity in other venomous organisms and have similar means of envenomation. Earlier studies suggested that Brown spiders (Loxosceles genus) venom comprised toxins supplemented with metalloproteinase, phospholipase D, hyaluronidase, and phosphatase [26]. Brown spider accidental bites can cause skin degeneration, intense inflammatory reaction, platelet aggregation, intravascular hemolysis, and cause thrombocytopenia. Phospholipase $\mathrm{D}$ is a dermonecrotic toxin that generates necrotic lesions, platelet aggregation, hemolysis, cell cytotoxicity, nephrotoxicity, enhanced vessel permeability, and death in animals [26,27]. According to earlier research, a novel membrane disrupting toxin identified in Vespa mandaria venom can cause intense pain, dermal necrosis, edema, and tissue damage [28]. For the present study, MALDI/TOF/MS was used to identify the differentially abundant proteins upon the treatment of NnV. Among 44 differentially expressed identified proteins, 25 proteins shown diminished volume, whereas 19 proteins exhibited an increment in volume after $\mathrm{NnV}$ treatment. Identified proteins are shown in Table 2 . The fold change and $p$-value of these identified proteins are summed up in the Supplementary Table S1. The representative MALDI/TOF/MS spectra of 4 identified proteins of interest are provided in Supplementary Figure S1, such as Vinculin, Plasminogen, Emilin, and Focal adhesion kinase 1. 
Table 2. Relative abundance of proteins affected by N. nomurai venom treatment in HaCaT cells.

\begin{tabular}{|c|c|c|c|c|c|c|c|c|}
\hline Spot No & $\begin{array}{l}\text { Accession } \\
\text { Number }^{1}\end{array}$ & Protein Name & Uniprot ID & $\begin{array}{c}\text { Theoretical } \\
\mathrm{MW} / \mathrm{Pi}^{2}\end{array}$ & Gene & $\begin{array}{l}\text { Matched } \\
\text { Peptide }^{3}\end{array}$ & $\begin{array}{l}\text { MOWSE } \\
\text { Score }\end{array}$ & Biological Process \\
\hline \multicolumn{9}{|c|}{ Proteins down-regulated by $\mathrm{NnV}$} \\
\hline 2319 & P18206 & Vinculin & VINC_HUMAN & $123,800 / 5.5$ & VCL & $36.80 \%$ & $1.64 \times 10^{14}$ & $\begin{array}{l}\text { epithelial cell-cell adhesion, } \\
\text { cell-matrix adhesion }\end{array}$ \\
\hline 1901 & Q9Y6U3 & Adseverin & ADSV_HUMAN & $80,490 / 5.5$ & SCIN & $27.30 \%$ & $6.09 \times 10^{6}$ & $\begin{array}{l}\text { regulation of chondrocyte } \\
\text { differentiation, negative } \\
\text { regulation of cell population } \\
\text { proliferation }\end{array}$ \\
\hline 1417 & O95259 & $\begin{array}{c}\text { Potassium } \\
\text { voltage-gated } \\
\text { channel } \\
\text { subfamily H } \\
\text { member } 1\end{array}$ & KCNH1_HUMAN & $111,424 / 7.5$ & KCNH1 & $20.10 \%$ & $20.10 \%$ & $\begin{array}{l}\text { regulation of cell } \\
\text { proliferation, myoblast } \\
\text { fusion, potassium ion } \\
\text { transport }\end{array}$ \\
\hline 1989 & Q9NQ38 & $\begin{array}{l}\text { Serine protease } \\
\text { inhibitor } \\
\text { Kazal-type } 5\end{array}$ & ISK5_HUMAN & $120,716 / 8.5$ & SPINK5 & $19.3 \%$ & $2.09 \times 10^{7}$ & $\begin{array}{c}\text { extracellular matrix } \\
\text { organization, epidermal cell } \\
\text { differentiation, regulation of } \\
\text { T cell differentiation }\end{array}$ \\
\hline 1956 & P14210 & $\begin{array}{l}\text { Hepatocyte } \\
\text { growth factor }\end{array}$ & HGF_HUMAN & $83,135 / 8.2$ & HGF & $28.2 \%$ & $2.65 \times 10^{7}$ & $\begin{array}{l}\text { activation of MAPK activity, } \\
\text { epithelial to mesenchymal } \\
\text { transition, mitotic cell cycle }\end{array}$ \\
\hline 1937 & Q6ZMZ3 & Nesprin-3 & SYNE3_HUMAN & $112,217 / 5.9$ & SYNE3 & $18.60 \%$ & $9.88 \times 10^{7}$ & $\begin{array}{l}\text { cytoskeletal anchoring at the } \\
\text { nuclear membrane, nuclear } \\
\text { migration, regulation of cell } \\
\text { shape }\end{array}$ \\
\hline 1937 & P00747 & Plasminogen & PLMN_HUMAN & $90,570 / 7.0$ & PLG & $19.30 \%$ & $2.15 \times 10^{6}$ & $\begin{array}{l}\text { blood coagulation, } \\
\text { fibrinolysis, proteolysis, } \\
\text { platelet degranulation }\end{array}$ \\
\hline 1649 & P16234 & $\begin{array}{l}\text { Platelet-derived } \\
\text { growth factor } \\
\text { receptor alpha }\end{array}$ & PGFRA_HUMAN & $122,671 / 5.1$ & PDGFRA & $26.40 \%$ & $5.01 \times 10^{8}$ & $\begin{array}{l}\text { double-strand break repair, } \\
\text { signal transduction, histone } \\
\text { deacetylation }\end{array}$ \\
\hline 816 & O43707 & Alpha-actinin-4 & ACTN4_HUMAN & $104,855 / 5.3$ & ACTN4 & $31.60 \%$ & $4.53 \times 10^{9}$ & $\begin{array}{c}\text { actin filament bundle } \\
\text { assembly, positive regulation } \\
\text { of NIK/NF-kappa B } \\
\text { signaling }\end{array}$ \\
\hline 1052 & P54762 & $\begin{array}{l}\text { Ephrin type-B } \\
\text { receptor } 1\end{array}$ & EPHB1_HUMAN & $109,886 / 6.0$ & EPHB1 & $29.4 \%$ & $9.78 \times 10^{8}$ & $\begin{array}{l}\text { cell differentiation, } \\
\text { cell-substrate adhesion, } \\
\text { angiogenesis }\end{array}$ \\
\hline 1915 & O00203 & $\begin{array}{c}\text { Ubiquitin } \\
\text { carboxyl- } \\
\text { terminal } \\
\text { hydrolase } 36\end{array}$ & UBP36_HUMAN & $122,653 / 9.7$ & USP36 & $14.90 \%$ & $1.72 \times 10^{6}$ & $\begin{array}{c}\text { negative regulation of } \\
\text { macroautophagy, regulation } \\
\text { of protein stability, nucleolus } \\
\text { organization }\end{array}$ \\
\hline 1793 & Q9UBK2 & $\begin{array}{l}\text { Peroxisome } \\
\text { proliferator- } \\
\text { activated } \\
\text { receptor gamma } \\
\text { coactivator } \\
\text { 1-alpha }\end{array}$ & PRGC1_HUMAN & $91,028 / 5.7$ & PPARGC1A & $19.00 \%$ & $3.55 \times 10^{7}$ & $\begin{array}{l}\text { regulation of transcription, } \\
\text { DNA-templated, response to } \\
\text { reactive oxygen species, } \\
\text { response to ischemia }\end{array}$ \\
\hline 2057 & Q5T0W9 & Protein FAM83B & TMF1_HUMAN & $114,800 / 9.0$ & FAM83B & $28.8 \%$ & $3.02 \times 10^{12}$ & $\begin{array}{l}\text { cell proliferation, epidermal } \\
\text { growth factor receptor } \\
\text { signaling pathway }\end{array}$ \\
\hline 1903 & Q6ZN19 & $\begin{array}{l}\text { Zinc finger } \\
\text { protein } 841\end{array}$ & ZN841_HUMAN & $93,149 / 9.5$ & ZNF841 & $23.1 \%$ & $2.49 \times 10^{6}$ & $\begin{array}{l}\text { transcription, transcription } \\
\text { regulation }\end{array}$ \\
\hline 1420 & Q6ZN30 & $\begin{array}{l}\text { Zinc finger } \\
\text { protein } \\
\text { basonuclin-2 }\end{array}$ & BNC2_HUMAN & $122,331 / 6.1$ & BNC2 & $27.00 \%$ & $1.71 \times 10^{1}$ & $\begin{array}{l}\text { endochondral bone growth, } \\
\text { mesenchyme development }\end{array}$ \\
\hline 1424 & Q9Y6C2 & $\begin{array}{c}\text { Elastin } \\
\text { microfibril } \\
\text { interface located } \\
\text { protein } 1 \\
(\text { EMILIN-1) }\end{array}$ & EMIL1_HUMAN & $106,696 / 5.1$ & EMILIN1 & $20.5 \%$ & $3.88 \times 10^{7}$ & $\begin{array}{c}\text { cell-matrix adhesion, } \\
\text { negative regulation of } \\
\text { collagen biosynthetic } \\
\text { process }\end{array}$ \\
\hline 1792 & Q9UMS6 & Synaptopodin-2 & SYNP2_HUMAN & $117,515 / 8.8$ & SYNPO2 & $27.3 \%$ & $9.57 \times 10^{8}$ & $\begin{array}{c}\text { positive regulation of cell } \\
\text { migration, } \\
\text { chaperone-mediated } \\
\text { autophagy }\end{array}$ \\
\hline
\end{tabular}


Table 2. Cont.

\begin{tabular}{|c|c|c|c|c|c|c|c|c|}
\hline Spot No & $\begin{array}{l}\text { Accession } \\
\text { Number }^{1}\end{array}$ & Protein Name & Uniprot ID & $\begin{array}{c}\text { Theoretical } \\
\text { MW/Pi }^{2}\end{array}$ & Gene & $\begin{array}{l}\text { Matched } \\
\text { Peptide }^{3}\end{array}$ & $\begin{array}{l}\text { MOWSE } \\
\text { Score }\end{array}$ & Biological Process \\
\hline 1423 & Q05397 & $\begin{array}{l}\text { Focal adhesion } \\
\quad \text { kinase } 1\end{array}$ & FAK1_HUMAN & $119,234 / 6.2$ & PTK2 & $20.80 \%$ & $5.88 \times 10^{6}$ & $\begin{array}{c}\text { positive regulation of cell } \\
\text { migration, } \\
\text { chaperone-mediated } \\
\text { autophagy }\end{array}$ \\
\hline 1266 & Q12866 & $\begin{array}{l}\text { Tyrosine-protein } \\
\text { kinase Mer }\end{array}$ & MERTK_HUMAN & $110,250 / 5.5$ & MERTK & $16.90 \%$ & $2.50 \times 10^{8}$ & $\begin{array}{l}\text { apoptotic cell clearance, cell } \\
\text { differentiation, phagocytosis }\end{array}$ \\
\hline 1933 & Q96NW4 & $\begin{array}{l}\text { Mismatch repair } \\
\text { endonuclease } \\
\text { PMS2 }\end{array}$ & ANR27_HUMAN & $116,985 / 6.4$ & ANKRD27 & $33.90 \%$ & $2.92 \times 10^{12}$ & mismatch repair \\
\hline 822 & P04150 & $\begin{array}{l}\text { Glucocorticoid } \\
\text { receptor }\end{array}$ & GCR_HUMAN & $85,660 / 6.0$ & NR3C1 & $32.60 \%$ & $7.99 \times 10^{11}$ & $\begin{array}{l}\text { cellular response to } \\
\text { glucocorticoid stimulus, } \\
\text { signal transduction }\end{array}$ \\
\hline 2233 & Q96M96 & $\begin{array}{l}\text { FYVE, RhoGEF } \\
\text { and PH domain- } \\
\text { containing } \\
\text { protein } 4\end{array}$ & FGD4_HUMAN & $86,627 / 5.8$ & FGD4 & $16.10 \%$ & $9.69 \times 10^{6}$ & $\begin{array}{l}\text { actin cytoskeleton } \\
\text { organization, regulation of } \\
\text { cell shape, cytoskeleton } \\
\text { organization }\end{array}$ \\
\hline 1944 & Q13342 & $\begin{array}{l}\text { Nuclear body } \\
\text { protein SP140 }\end{array}$ & SP140_HUMAN & $98,224 / 5.2$ & SP140 & $35.60 \%$ & $1.39 \times 10^{9}$ & defense response \\
\hline 1166 & O14730 & $\begin{array}{l}\text { Serine/threonine- } \\
\text { protein kinase } \\
\text { RIO3 }\end{array}$ & RIOK3_HUMAN & $59,094 / 5.5$ & RIOK3 & $26.40 \%$ & $4.31 \times 10^{6}$ & $\begin{array}{l}\text { positive regulation of } \\
\text { interferon-beta production, } \\
\text { cellular response to dsDNA, } \\
\text { innate immune response }\end{array}$ \\
\hline 1553 & Q13563 & Polycystin-2 & PKD2_HUMAN & $109,692 / 5.5$ & PKD2 & $19.90 \%$ & $1.20 \times 10^{8}$ & $\begin{array}{l}\text { cellular response to osmotic } \\
\text { stress, regulation of cell } \\
\text { proliferation, positive } \\
\text { regulation of cell cycle arrest }\end{array}$ \\
\hline 1421 & O43182 & $\begin{array}{l}\text { Rho GTPase- } \\
\text { activating } \\
\text { protein } 6\end{array}$ & RHG06_HUMAN & $105,948 / 7.0$ & ARHGAP6 & $27.60 \%$ & $9.16 \times 10^{7}$ & $\begin{array}{l}\text { inflammatory response, } \\
\text { transmembrane transport }\end{array}$ \\
\hline \multicolumn{9}{|c|}{ Proteins up-regulated by $\mathrm{NnV}$} \\
\hline 2250 & O75330 & $\begin{array}{l}\text { Hyaluronan } \\
\text { mediated } \\
\text { motility receptor }\end{array}$ & ZN33B_HUMAN & $84,101 / 5.7$ & HMMR & $35.5 \%$ & $5.68 \times 10^{9}$ & $\begin{array}{l}\text { Hyaluronan catabolic } \\
\text { process, regulation of } \mathrm{G} 2 / \mathrm{M} \\
\text { transition of mitotic cell } \\
\text { cycle }\end{array}$ \\
\hline 1562 & P15144 & $\underset{\mathrm{N}}{\text { Aminopeptidase }}$ & AMPN_HUMAN & $109,541 / 5.3$ & ANPEP & $34.20 \%$ & $5.11 \times 10^{11}$ & $\begin{array}{l}\text { cell differentiation, } \\
\text { proteolysis }\end{array}$ \\
\hline 1978 & Q86VD1 & $\begin{array}{l}\text { MORC family } \\
\text { CW-type zinc } \\
\text { finger protein } 1\end{array}$ & MORC1_HUMAN & $112,882 / 8.1$ & MORC1 & $20.80 \%$ & $8.49 \times 10^{6}$ & $\begin{array}{c}\text { negative regulation of } \\
\text { transposition, cell } \\
\text { differentiation, multicellular } \\
\text { organism development }\end{array}$ \\
\hline 2020 & P51784 & $\begin{array}{l}\text { Ubiquitin } \\
\text { carboxyl- } \\
\text { terminal } \\
\text { hydrolase } 11\end{array}$ & UBP11_HUMAN & $109,818 / 5.3$ & USP11 & $23.90 \%$ & $1.19 \times 10^{10}$ & $\begin{array}{l}\text { ubiquitin-dependent protein } \\
\text { catabolic process, protein } \\
\text { deubiquitination }\end{array}$ \\
\hline 1378 & O00206 & $\begin{array}{c}\text { Toll-like receptor } \\
4\end{array}$ & TLR4_HUMAN & $95,681 / 5.9$ & TLR4 & $31.90 \%$ & $6.08 \times 10^{8}$ & $\begin{array}{l}\text { activation of MAPK activity, } \\
\text { B cell proliferation involved } \\
\text { in immune response }\end{array}$ \\
\hline 2080 & Q8N392 & $\begin{array}{l}\text { Rho GTPase- } \\
\text { activating } \\
\text { protein } 18\end{array}$ & RHG18_HUMAN & $96,255 / 7.3$ & ARHGAP18 & $21.40 \%$ & $8.53 \times 10^{6}$ & $\begin{array}{l}\text { actin filament organization, } \\
\text { phagocytosis, engulfment }\end{array}$ \\
\hline 2514 & Q86UV5 & $\begin{array}{l}\text { Ubiquitin } \\
\text { carboxyl- } \\
\text { terminal } \\
\text { hydrolase } 48\end{array}$ & UBP48_HUMAN & $119,033 / 5.7$ & USP48 & $21.50 \%$ & $8.78 \times 10^{7}$ & $\begin{array}{l}\text { protein deubiquitination, } \\
\text { ubiquitin-dependent protein } \\
\text { catabolic process }\end{array}$ \\
\hline 1696 & Q969V6 & $\begin{array}{c}\text { MKL/myocardin- } \\
\text { like protein } \\
1\end{array}$ & MKL1_HUMAN & $98,920 / 5.6$ & Q969V6 & $28.20 \%$ & $1.57 \times 10^{7}$ & $\begin{array}{l}\text { actin cytoskeleton } \\
\text { organization, smooth muscle } \\
\text { cell differentiation }\end{array}$ \\
\hline 1929 & Q9Y4L1 & $\begin{array}{l}\text { Hypoxia } \\
\text { up-regulated } \\
\text { protein } 1\end{array}$ & HYOU1_HUMAN & $111,336 / 5.2$ & Q9Y4L1 & $31.20 \%$ & $1.45 \times 10^{10}$ & $\begin{array}{l}\text { cellular response to Hypoxia, } \\
\text { response to ischemia, } \\
\text { receptor-mediated } \\
\text { endocytosis }\end{array}$ \\
\hline 1590 & Q14587 & $\begin{array}{c}\text { Heat shock } \\
\text { protein } 105 \mathrm{kDa}\end{array}$ & ZN268_HUMAN & $96,866 / 5.3$ & ZNF268 & $23.00 \%$ & $5.01 \times 10^{7}$ & $\begin{array}{l}\text { receptor-mediated } \\
\text { endocytosis, regulation of } \\
\text { cellular response to heat, } \\
\text { positive regulation of NK T } \\
\text { cell activation }\end{array}$ \\
\hline
\end{tabular}


Table 2. Cont.

\begin{tabular}{|c|c|c|c|c|c|c|c|c|}
\hline Spot No & $\begin{array}{l}\text { Accession } \\
\text { Number }^{1}\end{array}$ & Protein Name & Uniprot ID & $\begin{array}{c}\text { Theoretical } \\
\mathrm{MW} / \mathrm{Pi}^{2}\end{array}$ & Gene & $\begin{array}{l}\text { Matched } \\
\text { Peptide }^{3}\end{array}$ & $\begin{array}{l}\text { MOWSE } \\
\text { Score }\end{array}$ & Biological Process \\
\hline 1198 & Q96FS4 & $\begin{array}{l}\text { Signal-induced } \\
\text { proliferation- } \\
\text { associated } \\
\text { protein } 1\end{array}$ & SIPA1_HUMAN & $112,150 / 6.2$ & SIPA1 & $15.90 \%$ & $1.91 \times 10^{6}$ & $\begin{array}{l}\text { cell proliferation, negative } \\
\text { regulation of cell growth, } \\
\text { negative regulation of cell } \\
\text { cycle }\end{array}$ \\
\hline 1555 & Q5T7N2 & $\begin{array}{l}\text { LINE-1 type } \\
\text { transposase } \\
\text { domain- } \\
\text { containing } \\
\text { protein } 1\end{array}$ & LITD1_HUMAN & $98,850 / 4.9$ & L1TD1 & $18.20 \%$ & $1.50 \times 10^{6}$ & $\begin{array}{l}\text { transposition, } \\
\text { RNA-mediated }\end{array}$ \\
\hline 1886 & P15918 & $\begin{array}{l}\mathrm{V}(\mathrm{D}) \mathrm{J} \\
\text { recombination- } \\
\text { activating } \\
\text { protein } 1\end{array}$ & RAG1_HUMAN & $119,098 / 8.9$ & RAG1 & $15.8 \%$ & $1.42 \times 10^{6}$ & $\begin{array}{l}\text { B cell differentiation, } \mathrm{T} \text { cell } \\
\text { homeostasis, negative } \\
\text { regulation of thymocyte } \\
\text { apoptotic process }\end{array}$ \\
\hline 710 & A6NI28 & $\begin{array}{l}\text { Rho GTPase- } \\
\text { activating } \\
\text { protein } 42\end{array}$ & RHG42_HUMAN & $98,570 / 8.2$ & ARHGAP42 & $26.9 \%$ & $2.94 \times 10^{7}$ & $\begin{array}{c}\text { activation of GTPase activity, } \\
\text { negative regulation of } \\
\text { vascular smooth muscle } \\
\text { contraction }\end{array}$ \\
\hline 2199 & P21709 & $\begin{array}{l}\text { Ephrin type-A } \\
\text { receptor } 1\end{array}$ & EPHA1_HUMAN & $108,128 / 6.2$ & EPHA1 & $22.0 \%$ & $3.45 \times 10^{9}$ & $\begin{array}{l}\text { negative regulation of cell } \\
\text { migration, cell surface } \\
\text { receptor signaling pathway }\end{array}$ \\
\hline 1389 & Q93033 & $\begin{array}{l}\text { Immunoglobulin } \\
\text { superfamily } \\
\text { member } 2\end{array}$ & IGSF2_HUMAN & $115,109 / 6.5$ & CD101 & $22.9 \%$ & $1.59 \times 10^{12}$ & $\begin{array}{l}\text { cell surface receptor } \\
\text { signaling pathway, positive } \\
\text { regulation of myeloid } \\
\text { leukocyte differentiation }\end{array}$ \\
\hline 2305 & Q4V348 & $\begin{array}{l}\text { Zinc finger } \\
\text { protein } 658 \mathrm{~B}\end{array}$ & Z658B_HUMAN & $94,332 / 8.9$ & ZNF658B & $25.40 \%$ & $1.51 \times 10^{7}$ & $\begin{array}{l}\text { bile acid biosynthetic } \\
\text { process }\end{array}$ \\
\hline 1122 & Q02156 & $\begin{array}{l}\text { Protein kinase C } \\
\text { epsilon type }\end{array}$ & KPCE_HUMAN & $83,675 / 6.7$ & PRKCE & $30.10 \%$ & $1.18 \times 10^{8}$ & $\begin{array}{l}\text { apoptotic process, apoptotic } \\
\text { process, }\end{array}$ \\
\hline 1491 & P49736 & $\begin{array}{l}\text { DNA replication } \\
\text { licensing factor } \\
\text { MCM2 }\end{array}$ & MCM2_HUMAN & $101,897 / 5.3$ & MCM2 & $26.0 \%$ & $9.15 \times 10^{8}$ & $\begin{array}{l}\text { apoptotic process, apoptotic } \\
\text { process, DNA replication } \\
\text { initiation, nucleosome } \\
\text { assembly }\end{array}$ \\
\hline 1827 & P35527 & $\begin{array}{l}\text { Keratin, type I } \\
\text { cytoskeletal } 9\end{array}$ & K1C9_HUMAN & $62,065 / 5.1$ & KRT9 & $20.50 \%$ & $1.04 \times 10^{6}$ & $\begin{array}{l}\text { intermediate filament } \\
\text { organization, cornification }\end{array}$ \\
\hline
\end{tabular}

${ }^{1}$ Accession numbers predicted by Swiss-Prot. ${ }^{2}$ Theoretical mass (MW) and Pi reported in Swiss-Prot. ${ }^{3}$ Percentage of amino acids sequence coverage of matched peptides for the identified proteins.

\subsection{Peroxisome Proliferator-Activated Receptor $\gamma$ Coactivator $1 \alpha(P G C-1 \alpha)$}

Our proteomic result illustrated that the protein level of Peroxisome proliferatoractivated receptor $\gamma$ coactivator $1 \alpha$ (PGC- $1 \alpha$ ) was reduced after venom treatment. PGC- $1 \alpha$ is a transcriptional coactivator that regulates the expression of antioxidant genes to modulate the oxidative stress response [29]. The class of 209 known environmental pollutants represents Polychlorinated biphenyls (PCBs) [29]. Monochlorobiphenyl (PCB3) is a semivolatile $\mathrm{PCB}$ congener whose traces were found in human blood samples, commercial paints, and the polluted environment. 1-(4-Chlorophenyl)-benzo-2,5-quinone (4-ClBQ) is a metabolite of 4-monochlorobiphenyl, PCB3. Earlier studies showed that 4-ClBQ exposure impedes the activity of PGC-1 $\alpha$ [29] and expression of catalase, which directly associates with an upsurge in cellular reacted oxygen species (ROS) levels and toxicity in $\mathrm{HaCaT}$ cells [29]. PGC-1 $\alpha$ is also down regulated after the treatment with $\mathrm{NnV}$, leading to toxicity in $\mathrm{HaCaT}$ cells.

\subsection{Elastin Microfibril Interface Located Protein 1 (EMILIN-1)}

EMILIN's belong to the protein family dominant in the extracellular matrix and possess a distinctive structural domain configuration. Until now, four such genes were known in humans and mice [30]. EMILIN-1 (Elastin microfibril interface located protein 1) comprises $\mathrm{N}$ terminal cysteine-rich EMI domain, coiled-coil alpha-helical domain, collagenous domain, and qc1qlike domain [30]. EMILIN-1 is a multifunctional protein involved in cell migration, proliferation, and cell adhesion. Emilin-1 is found in various connective tissues, e.g., lung and blood vessels [31]. EMILIN-1 is also present in the dermis and plays an important role in maintaining the 3D structure of the extracellular matrix [32]. Earlier studies 
suggested that antibodies counter to EMILIN-1 repressed elastin deposition by smooth muscle cells (in vitro) and proposed that this protein may lead to elastogenesis [30,31]. EMILIN-1 promotes vascular cell maintenance by steadying molecular interactions between elastic fiber components and providing specific cell adhesion properties to elastic fibers [30-34]. Earlier studies suggested that the absence of EMILIN-1 resulted in elastogenesis and vascular cell defects [34]. Our results showed that EMILIN-1 level was decreased after $\mathrm{NnV}$ treatment and hinted toward the severe damage caused by $\mathrm{NnV}$ to $\mathrm{HaCaT}$ cells.

\subsection{Basonuclin 2}

Basonuclin 2 is a transcription factor that belongs to a member of the Basonuclin zincfinger family proteins present in germ tissues, corneal epithelium, basal skin keratino- cytes stratified squamous epithelium and also expressed in hair follicles keratinocytes [35]. It acts as a transcription factor and generates nuclear function by regulating gene expression in different types of cells [35]. It plays a crucial role in the growth of craniofacial bones and male germ cells. The lack of Basonuclin 2 gene expression in mice leads to neonatal lethality correlated with cleft palate and craniofacial deformity. Thus, the reduced activity of Basonuclin 2 can result in human craniofacial abnormalities. Earlier research suggested that Basonuclin 2 is vital for typical mitotic arrest, prevention of premature meiotic initiation, and meiotic progression in mouse male germ cells [35,36]. Basonuclin 2 also plays an essential role in the multiplication of embryonic craniofacial mesenchymal cells and is orthologous to disco proteins [36-38]. The current studies evaluated Basonuclin 2 protein was decreased in abundance in $\mathrm{NnV}$ treated $\mathrm{HaCaT}$ cell after $12 \mathrm{~h}$ and $24 \mathrm{~h}$ treatment. A reduced amount of Basonuclin 2 supports the severe $\mathrm{NnV}$ induced toxicity in $\mathrm{HaCaT}$ cells.

\subsection{Glucocorticoid (GC)}

Glucocorticoid (GC) derivatives are the utmost efficient and extensively referred compounds for curing inflammatory and autoimmune diseases [39]. GC deficiency can cause Addison's disease and result in skin alterations, suggesting that proper GC levels are essential for regular tissue function [39-42]. Former studies indicated that epidermal depletion of GR disrupts the epidermal barrier by augmented proliferation and impaired differentiation [40-43]. It was shown earlier that epidermal GR and mineralocorticoid receptor [MR] work mutually to control epidermal development and respond to skin inflammation [42]. Similarly, in the current case, it might be concluded that the low abundance of glucocorticoid (GC) may also lead to dermal toxicity in $\mathrm{NnV}$ treated HaCaT cells.

\subsection{Plasminogen}

Ubiquitous plasminogen activates Plasmin by the action of cell-derived urokinase-type (uPA) or tissue-type (tPA) plasminogen activator [44]. Plasmin is a fibrinolytic protease. Earlier studies suggested that uPA mediated plasminogen activation contributes to the process of human skin wound healing [44]. Henceforth plasminogen activation system signifies an essential molecular mechanism of extracellular protein degradation and is an effective component of typical wound healing. The plasminogen activation system significantly contributes to tissue remodeling, and tissue-type plasminogen activator (tPA) primarily deals with intravascular fibrinolysis [44-46]. During inflammation plasminogen activator system is engaged in complement activation, inflammatory cell migration, and cell signaling. Plasminogen (plg) deficient and wild-type (wt) mice models were used to investigate the function of plg in cutaneous wound healing [44-46]. It was found that plg deficient mice showed delayed wound healing and inflammation augmentation after two months of injury. It was also reported that when plg deficient mice were injected intravenously with human plg, it showed declined inflammation and alleviation in the wound healing $[46,47]$. All of the evidence resolutely indicates that plasminogen is a promising drug substitute to treat non-healing chronic wounds. It was reported that plasminogen activator inhibitor- 1 causes impaired wound healing in venous leg ulcers, and the level of tissue-type plasminogen activator (tPA) expression is changed in keratinocytes 
at the site of injury [47]. Our proteomic results showed that plasminogen volume is declined after $\mathrm{NnV}$ treatment, proposing a probable mechanism of actions for $\mathrm{NnV}$-induced dermal toxicity.

\subsection{Vinculin}

An Actin filament (F-actin)-binding protein Vinculin plays a vital role in cell-matrix adhesion and cell-cell adhesion. Vinculin modulates the expression of cell-surface Ecadherin and accelerates the mechanosensing by the E-cadherin complex [48]. Vinculin controls cell signaling and affects cell contractility and adhesion-site turnover [48,49]. An inadequate amount of Vinculin in cells causes a deformity in cell migration, cell spreading, cell-matrix adhesion, and focal adhesion turnover. Earlier research revealed that the downregulation of Vinculin in atherosclerotic plaque leads to disorganized tissue, increase sensitivity to mechanical injury, and delayed healing processes [49]. Vinculin sh RNA knockdown/substitution model system notably proposed that the deprivation of vinculin cause deterioration of epithelial cell-cell adhesion due to the reduction in cell surface expression of E. cadherin $[48,49]$. We also observed a decrease in the expression of Vinculin after NnV treatment.

\subsection{Focal Adhesion Kinase 1}

Focal adhesion kinase 1 plays a crucial role in modulating cell adhesion, spreading, migration, actin cytoskeleton reorganization, formation and disassembly of focal adhesions and cell protrusions, cell cycle progression, apoptosis and cell proliferation [50,51]. It was reported earlier that focal adhesion kinase functions upstream of phosphatidylinositol 3-kinase/Akt. It regulates fibroblast survival in retort to shrinkage of Type I collagen matrices by an integrin Beta 1-viability signaling pathway [51]. It was observed earlier that focal adhesion Kinase 1 triggers the migration and proliferation of keratinocytes at epidermal injury site [52]. Thus, focal adhesion Kinase 1 seems to have a crucial role in the reepithelization of human wounds. Our data show a decrement in Focal adhesion Kinase 1 volume in response to $\mathrm{NnV}$, suggesting that $\mathrm{NnV}$ can affect cell cytoskeleton and cause dermal toxicity with compulsive disorders.

\subsection{Myocardin Related Transcription Factor-A (MRTF-A)}

A transcriptional coactivator named Myocardin related transcription factor-A (MRTFA) is known to be dominantly localized in the cytoplasm and but during mechanical stress or growth factor stimulation, it translocates to the nucleus [53]. The activity of MRTF-A increase in a time-dependent manner during scleroderma (systemic sclerosis, SSc), and lower expression of MRTF-A or any hindrance in nuclear translocation may affect the development of fibrosis in SSc skin [54]. The basal skin and lung stiffness were reduced in the MRTF-A null mouse due to changes in fibrillar collagen. MRTF-A plays a vital role in SSc fibrosis, and it remodels the extracellular matrix in response to mechanical signals [55]. Increased protein level of MRTF-A in HaCaT cells post-NnV treatment clues severely damaged human keratinocytes by $\mathrm{NnV}$.

\subsection{Toll-Like Receptors (TLRs)}

A membrane-localized pattern recognition receptor named Toll-like receptors (TLRs) is a component of the endogenous immune system. TLRs participate in the signal transduction pathway involved in response to inflammation and plays a significant role in the endogenous immune response [56-58]. Exposure to solar UVB irradiation may lead to sunburn, erythema, oxidative stress and apoptosis, and activation of various signaling pathways, including the toll-like receptor (TLR)4 [58]. It suggests that (TLR)4 is crucial in the progression of inflammatory response and pathogenesis of inflammatory skin diseases. The level of the toll-like receptor (TLR) 4 is high after $\mathrm{NnV}$ treatment, proposing a probable mechanism of action for $\mathrm{NnV}$-induced dermal toxicity in $\mathrm{HaCaT}$ cells. 


\subsection{Minichromosome Maintenance (MCM)}

The Minichromosome maintenance (MCM) is cycling cell-specific initiation factors for DNA replication [59] which dominantly express during actinic keratosis (AK) in atypical keratinocytes [60]. AK is a precancerous lesion of the skin with variable rates of transformation into non-melanocytic carcinomas [61]. MCM 2 protein acts as a diagnostic marker for AK [61]. Our data shows elevation in MCM 2 protein level in response to venom treatment, suggesting that $\mathrm{NnV}$ can cause dermal toxicity and severe pathological disorder.

\subsection{APN/CD13 (Aminopeptidase N)}

APN/CD13 (Aminopeptidase N) is a zinc-dependent transmembrane ectopeptidase, it mainly split neutral amino acids from the N-terminus of peptides. Besides, APN/CD13 is also involved in extracellular matrix (ECM) degradation [62,63]. It was previously reported that APN/CD13 express in dermal, gingival fibroblasts, and dermatological/rheumatic diseases derived human fibroblasts [63,64]. Psoriasis vulgaris is a well-known skin inflammatory disease that leads to scaly well-demarcated skin plaques accompanied by a burning sensation. In psoriatic fibroblasts, APN/CD13 is over-expressed and showed higher activity as compared with HD fibroblasts $[63,64]$. Our results are in conjunction with previous findings, which also shown a significant increase in APN/CD13 (Aminopeptidase $\mathrm{N}$ ) protein volume in $\mathrm{NnV}$ treated $\mathrm{HaCaT}$ cells.

\section{Conclusions}

In conclusion, $\mathrm{NnV}$ consists of various ingredients, which are ample in toxin proteins and peptides, cause local and systematic inflammatory responses after accidental stinging. In current study $\mathrm{NnV}$ has altered the pathways related to immune response, cell adhesion, actin cytoskeleton, apoptosis, cell cycle, blood coagulation. Our previous studies explored that metalloproteinase, phospholipase, and other toxins components result in pathogenesis generated by the $\mathrm{NnV}$ after stings. From protein interaction network analysis, we have found that focal adhesion kinase (PTK2) is in the center of network and upstream of Vinculin (VCL) and $\alpha$-Actinin-4. Focal adhesion kinase (PTK2) level was decreased after NnV treatment which leads to decreased abundance of VCL and $\alpha$-Actinin-4. All these proteins have an influential role in cell-matrix adhesion, spreading, migration, actin cytoskeleton reorganization, formation and disassembly of focal adhesions and cell protrusions, cell cycle progression, apoptosis and cell proliferation. Further extensive studies are needed to demonstrate the detailed mechanism and role of these target candidate proteins in the dermal toxicity caused by NnV. Mainly toll-like receptor (TLR)4 plays a central role in signal transduction pathway, cause progression of inflammation and pathogenesis of skin diseases. However, we have evaluated that TLR4 level was increased in response to $\mathrm{NnV}$ treatment, which hints towards its role in sensing and relaying dermal toxicity and skin injury. Such a target-based study in the future could explore therapeutic care against Jellyfish envenomation. $\mathrm{NnV}$ inheres multitudinous enzymatic ingredients may significantly categorize promising bioactive components of $\mathrm{NnV}$, which leads to dermal toxicity. For the present study, we have focused on analyzed the proteome profiling to characterize NnV-induced dermal cell cytotoxicity.

\section{Remarks}

It is presumed that the present research may have imparted awareness dealing with $\mathrm{NnV}$ envenomation, their management, therapy and may provide an invaluable understanding of pernicious consequences of the $\mathrm{NnV}$ stinging.

\section{Materials and Methods}

\subsection{Chemicals and Reagents}

The chemicals used and manufacturer details are as follows: the sequencing grade modified trypsin (Promega, Corporation, Madison, WI, USA), acetonitrile (ACN), trifluoroacetic acid (Merck chemicals, Darmstadt, Germany), formic acid (Acros Organics BVBA, 
Geel, Belgium), Immobiline ${ }^{\mathrm{TM}}$ Dry strip ( $\mathrm{pH} 4-7,18 \mathrm{~cm}$ ), and iodoacetamide were bought from GE Healthcare life sciences (Marlborough, MA, USA). Most of other chemicals and reagents with analytical grade were purchased from Sigma Aldrich (St. Louis, MO, USA).

\subsection{Sample Collection and Preparation}

Numerous N. nomurai jellyfish specimens were collected from the Yellow Sea along the coast of Gunsan, South Korea. Tentacles were separated and transported to the lab instantly to the laboratory under ice-cold conditions for further examination. Nematocysts were isolated using the method as described previously [65]. The dissected tentacles were washed several times with cold seawater to remove salts and debris. To the washed tentacles, three volumes $(v / v)$ of cold seawater was added and kept on the shaker for $24 \mathrm{~h}$ at $4{ }^{\circ} \mathrm{C}$. Subsequently the tentacles free seawater was centrifuged at $1000 \times g$ for $5 \mathrm{~min}$, the pellet was collected and rinsed three times with seawater. Sedimented tentacles were further autolyzed in fresh seawater at $4{ }^{\circ} \mathrm{C}$ for one day as described above, and the autolysis process was repeated for 3-4 days. Finally, steady nematocysts were washed carefully several times with seawater. Nematocysts were collected at $500 \mathrm{~g}$ for $5 \mathrm{~min}$, and the supernatant was removed, nematocyst pellets were dried in freeze dryer lyophilizer. Lyophilized pellets were stored at $-80^{\circ} \mathrm{C}$ until further use.

\subsection{Venom Extraction and Preparation}

Venom was pulled out from the lyophilized-dried nematocysts employing the method designated by Carrette and Seymour [66] with minor modulations. In brief, venom was extracted from $50 \mathrm{mg}$ of nematocyst using glass beads (approximately 8000 beads; $0.5 \mathrm{~mm}$ in diameter) and $1 \mathrm{~mL}$ of ice-cold phosphate-buffered saline (PBS, $\mathrm{pH}$ 7.4). These samples were shaken in a mini bead mill at $3000 \mathrm{rpm}$ for $30 \mathrm{~s}$, repeated ten times with intermittent cooling on ice. The venom extracts were then transferred to a new Eppendorf tube and centrifuged $(22,000 \times g)$ at $4{ }^{\circ} \mathrm{C}$ for $30 \mathrm{~min}$. This supernatant was used as $\mathrm{NnV}$ for the present study. Bradford assay was explored (Bio-Rad, Hercules, CA, USA) [67] to determine the protein concentration of venom samples.

\subsection{Cell Culture}

The human keratinocytes cell lines $\mathrm{HaCaT}$ was obtained from the American Type Culture Collection (ATCC) (Manssas, VA, USA) and carefully cultured in Dulbecco's modified Eagle's medium (DMEM) comprising 10\% heat-inactivated fetal bovine serum (FBS), $100 \mu \mathrm{g} / \mathrm{mL}$ penicillin-streptomycin-amphotericin B solution. The cells were maintained in a humidified incubator at $37^{\circ} \mathrm{C}$, and with $5 \% \mathrm{CO}_{2}$, and their medium was replaced every 2-3 days.

\subsection{Conditions for MTT Assay for Cell Viability}

MTT (3-(4,5-dimethyl-2-yl)-2,5-diphenyltetrazolium bromide) reduction assay was used to measure cell viability. For the MTT assay, 24-well plates were used to seed the $\mathrm{HaCaT}$ cells at the density of $4 \times 10^{4}$ cells/well, and cells were grown for $24 \mathrm{~h}$. The concentrations ranging from $0-5 \mu \mathrm{g} / \mathrm{mL}$ of $\mathrm{NnV}$ were used to treat the cells for the next $24 \mathrm{~h}$. After $24 \mathrm{~h}$ incubation MTT dye $50 \mu \mathrm{L}(0-5 \mathrm{mg} / \mathrm{mL})$ was added to the cells in each well, and then cells were further incubated at $37^{\circ} \mathrm{C}$ for the next $3 \mathrm{~h}$. The supernatant was removed and replaced by $200 \mu \mathrm{L}$ of dimethyl sulfoxide (DMSO) in each well, and to solubilize the formazan salts produced during reaction plates were kept on the shaker for 10 min. GENios microplate spectrophotometer (PowerWave ${ }^{\mathrm{TM}}$ XS, BioTek Instruments, Inc., Winooski, VT, USA) was used to measure the absorbance of samples at $540 \mathrm{~nm}$. Probit analysis [68] was used to quantify the IC50 value. The phase-contrast microscope was used to analyze the morphological changes made by $\mathrm{NnV}$ treatment. Untreated cells were used as the control, minimum of three replicates were used for each sample to perform MTT assay. 


\subsection{DAPI Staining for Nuclear Morphological Analysis}

The $\mathrm{IC}_{50}$ concentration of $\mathrm{NnV}$ was used to treat the $24 \mathrm{~h}$ grown $\mathrm{HaCaT}$ cells $(1 \times$ $10^{4}$ cells/well) plated onto cell culture slide (SPL life science, Pocheon, Korea)for $12 \mathrm{~h}$ and $24 \mathrm{~h}$ to analyze the nuclear morphology. The cells on the slide were fixed with the $4 \%$ paraformaldehyde treatment for $15 \mathrm{~min}$. Followed by three washings each for $10 \mathrm{~min}$. Then cells were stained with DAPI solution, and images were taken under fluorescence microscopy.

\subsection{Protein Extraction and Sample Preparation}

The 2-DE protein samples were prepared from the HaCaT cells at $70 \%$ confluence were treated with $\mathrm{IC}_{50}$ concentration of $\mathrm{NnV}$ for 12 and $24 \mathrm{~h}$. The ice-cold $1 \mathrm{X}$ phosphatebuffered saline (PBS) was used to wash treated cells and 2-DE lysis buffer (7 M Urea, $2 \mathrm{M}$ thiourea, 4\% CHAPS (3-[(3-cholamidopropyl) dimethylammonio]-1 propane sulfonate, $10 \%$ DTT, $0.5 \%$ IPG buffer with $1 \%$ proteinase inhibitor was used to scrap the cells. Samples were vortexed for $30 \mathrm{~min}$ at $4{ }^{\circ} \mathrm{C}$ and the insoluble parts were removed by centrifugation $\left(14,000 \times g, 15 \mathrm{~min}, 4^{\circ} \mathrm{C}\right)$. To cell lysis supernatant, an equal volume of $20 \%$ TCA was added, the mixture was incubated for $30 \mathrm{~min}$ on ice and centrifuged at $14,000 \times \mathrm{g}$ for $15 \mathrm{~min}$ at $4{ }^{\circ} \mathrm{C}$. The supernatant was removed, and pellets were washed twice with $200 \mu \mathrm{L}$ of ice-cold acetone and centrifuged as above. Then the pellets were vacuum dried for 10-15 min. Subsequently, dried pellets were dissolved in a sample buffer containing ( $7 \mathrm{M}$ urea, $2 \mathrm{M}$ thiourea, $4 \%(w / v)$ CHAPS). The protein concentration of the samples was determined by using the Bradford assay.

\subsection{Two-Dimensional Gel Electrophoresis and Image Analysis}

The 2-DE was used to examined the differentially abundant proteins. A total of $300 \mu \mathrm{g}$ of protein samples were resuspended in $340 \mu \mathrm{L}$ of a rehydration buffer comprising (2 M thiourea, $7 \mathrm{M}$ urea, $4 \%(w / v)$ CHAPS, $10 \mathrm{mg} / \mathrm{mL}$ DTT, $1 \%$ pharmalytes $4-7$ and low amount of bromophenol blue). For the rehydration process, protein samples were loaded into the rehydration try. The $18 \mathrm{~cm}$ immobiline TM Dry strip ( $\mathrm{pH} 4-7$ ), were placed carefully on the rehydration try for overnight at room temperature. Through Ettan IPGphor system (GE Healthcare, Salt Lake City, UT, USA). Isoelectric focusing was achieved and procedure comprises series of subsequent sitting: $50 \mathrm{~V}$ for 1:00 h, $200 \mathrm{~V}$ for 1:00 $\mathrm{h}, 500 \mathrm{~V}$ for $0: 30 \mathrm{~h}$, gradient $4000 \mathrm{~V}$ for $0: 30 \mathrm{~h}, 4000 \mathrm{~V}$ for 1:00 h, gradient 10,000 V for 1:00 h, 10,000 V for 13:00 $\mathrm{h}$ and $50 \mathrm{~V} 3: 00 \mathrm{~h}$ at $20^{\circ} \mathrm{C}$. Strips were rinsed with a solution covering $50 \mathrm{mM}$ Tris- $\mathrm{HCl}$ (pH 8.8), $6 \mathrm{M}$ urea, 30\% glycerol, $2 \%$ SDS and $0.01 \%$ bromophenol blue containing $1 \% w / v$ DTT for undertaking reduction. Afterward, the reduced strips were wiped in an alkylation solution, integrated with $2.5 \% w / v$ iodoacetamide. After washing, the strips were positioned on the upper side of $18 \mathrm{~cm}, 12 \%$ SDS polyacrylamide gels, and fixed with $0.5 \%(w / v)$ agarose gel, including a bit of bromophenol blue. Concurrently in the second dimension, the proteins were resolved at $20 \mathrm{~mA} /$ gel at $20^{\circ} \mathrm{C}$.

For each sample, quadruplicate gels were prepared, and gels were silver stained, utilizing the technique described by Mortz et.al [69]. The image investigation was achieved with Progenesis Same Spots software (Nonlinear Dynamics, Newcastle, UK. For that, the gels were scanned and visualized by the Epson perfection V 700 photo scanner (Epson, Suwa, OU, Japan). The significant protein spots were recognized by editing program (which carried out, spot detection, background diminution, emulated spot, and entire spot volume normalization) to discover the differentially abundant protein spots. The distinctness in expression level between $\mathrm{HaCaT}$ cells and $\mathrm{HaCaT}-\mathrm{NnV}$ treated at a different time was evaluated statistically by one-way ANOVA depend upon value $p \leq 0.05$.

The analyzed protein spots showing the difference in expression were incised, taken out from 2-DE gels, and in-gel digestion of the proteins was acquired by the former technique [65]. For $10 \mathrm{~min}$, the gel bits were destained in $100 \mathrm{mM} \mathrm{Na}_{2} \mathrm{~S}_{2} \mathrm{O}_{3} 30 \mathrm{mM}$ potassium ferricyanide and $100 \mathrm{mM} \mathrm{Na}_{2} \mathrm{~S}_{2} \mathrm{O}_{3}(1: 1, v / v)$. $100 \% \mathrm{ACN}$ was used to dehydrate the gel bits and dried in a speed vacuum apparatus. Then the dried gels bits were reduced 
with (10 $\mathrm{mM}$ DTT in $100 \mathrm{mM}$ ammonium bicarbonate) reduction solution, incubated at $56{ }^{\circ} \mathrm{C}$ for $45 \mathrm{~min}$. Thenceforth the gel bits were alkylated $(100 \mathrm{mM}$ iodoacetamide in $100 \mathrm{mM}$ ammonium bicarbonate) alkylation solution, kept in a shaker for $45 \mathrm{~min}$ in the dark. After that that the gel bits were incubated in a digestion solution containing $50 \mathrm{mM}$ $\mathrm{NH}_{4} \mathrm{HCO}_{3}$ and $20 \mathrm{ng} / \mu \mathrm{L}$ trypsin on ice. After $45 \mathrm{~min}$ trypsin was taken out, a suitable amount of $50 \mathrm{mM} \mathrm{NH}_{4} \mathrm{HCO}_{3}$ was added, and gel bits Eppendorf were kept overnight at $37^{\circ} \mathrm{C}$. The tryptic peptide mixture was extracted with an extraction buffer containing $100 \%$ $\mathrm{ACN}$ and $50 \%$ TFA and concentrated in a vacuum centrifuge.

\subsection{MALDI-TOF/MS Analysis and Database Searching}

HCCAs matrix solution ( $\alpha$-acyano-4-hydroxycinnamic acid) $1 \mu \mathrm{L}$ and $1 \mu \mathrm{L}$ of extraction buffer were used to re-dissolve the peptide extract and spotted onto a clean MALDI-TOF plate. Voyager-DE STR mass spectrometer (Applied Biosystems, Franklin Lakes, NJ, USA) was used to record the mass spectrometry (MS) spectra. The reflection/delayed extraction mode was used to acquire the spectra. The spectra over a mass range of 800-3000 Da were recorded. Monoisotopic peptide masses over a mass range of 800-3000 Da were further analyzed. Protein identification was carried out by peptide mass fingerprinting (PMF) using the MS-Fit program (http:/ / prospector.ucsf.edu (accessed on 5 October 2018) and Mascot (Matrix science http:/ / www.matrixscience.com (accessed on 10 November 2018) in the Swiss-Prot databases. The following parameters were considered for the peptide search; carbamidomethylation of cysteines as a fixed modification, oxidation of methionine as variable modification, peptide mass tolerance of $\pm 10-70 \mathrm{ppm}$ for the fragment ions, trypsin with one missed cleavage was allowed. The number of the matched peptide, the extent of sequence coverage, and probability-based Mowse score was considered before accepting the identification.

\subsection{Statistical and Bioinformatics Analysis of Protein Identified by MALDI-TOF/MS}

One way analysis of variance (ANOVA) was used for the statistical analysis of differentially expressed proteins to evaluate the significance of the difference between the two mean values. $p<0.05$ and $p<0.01$ were taken as statistically significant. The Panther classification system (http:www.pantherdb.org/ (accessed on 19 January 2019) was used to classify data in terms of molecular function, biological process, protein class, and cellular components [70].

Supplementary Materials: The following are available online at https:/ /www.mdpi.com/article/10 $.3390 /$ toxins13050311/s1, Table S1: Proteins with significant fold changes identified from HaCaT cells treated with $N$. nomurai venom.

Author Contributions: Conceptualization, E.K.; methodology and investigation, I.C.; validation and formal analysis, D.H. and C.K.; resources and validation, J.C. and W.Y.; writing-original draft preparation, I.C.; writing — review and editing, E.K.; supervision and project administration, E.K.; funding acquisition, E.K. All authors have read and agreed to the published version of the manuscript.

Funding: This work was supported by the grant of the National Research Foundation of Korea (NRF-2017R1D1A1B03036005). This research was also a part of the project titled 'Improvement of Management Strategies on Marine Disturbing and Harmful Organisms' funded by the Ministry of Oceans and Fisheries, Korea.

Institutional Review Board Statement: Not applicable.

Informed Consent Statement: Not applicable.

Data Availability Statement: Not applicable.

Conflicts of Interest: The authors declare no conflict of interest. 


\section{References}

1. Dong, Z.; Liu, D.; Keesing, J.K. Jellyfish blooms in China: Dominant species, causes and consequences. Mar. Pollut. Bull. 2010, 60, 954-963. [CrossRef] [PubMed]

2. Omori, M.; Kitamura, M. Taxonomic review of three Japanese species of edible jellyfish(Scyphozoa: Rhizostomeae). Plankton Biol. Ecol. 2004, 51, 36-51.

3. Kang, C.; Munawir, A.; Cha, M.; Sohn, E.-T.; Lee, H.; Kim, J.-S.; Yoon, W.D.; Lim, D.; Kim, E. Cytotoxicity and hemolytic activity of jellyfish Nemopilema nomurai (Scyphozoa: Rhizostomeae) venom. Comp. Biochem. Physiol. Part C Toxicol. Pharmacol. 2009, 150, 85-90. [CrossRef] [PubMed]

4. Kim, E.; Lee, S.; Kim, J.-S.; Yoon, W.D.; Lim, D.; Hart, A.J.; Hodgson, W.C. Cardiovascular effects of Nemopilema nomurai (Scyphozoa: Rhizostomeae) jellyfish venom in rats. Toxicol. Lett. 2006, 167, 205-211. [CrossRef]

5. Choudhary, I.; Lee, H.; Pyo, M.-J.; Heo, Y.; Bae, S.K.; Kwon, Y.C.; Yoon, W.D.; Kang, C.; Kim, E. Proteomics approach to examine the cardiotoxic effects of Nemopilema nomurai jellyfish venom. J. Proteom. 2015, 128, 123-131. [CrossRef]

6. Kawahara, M.; Uye, S.-I.; Ohtsu, K.; Iizumi, H. Unusual population explosion of the giant jellyfish Nemopilema nomurai (Scyphozoa: Rhizostomeae) in East Asian waters. Mar. Ecol. Prog. Ser. 2006, 307, 161-173. [CrossRef]

7. Teragawa, C.K.; Bode, H.R. Migrating interstitial cells differentiate into neurons in hydra. Dev. Biol. 1995, 171, 286-293. [CrossRef]

8. Hausmann, K.; Holstein, T. Bilateral symmetry in the cnidocil-nematocyst complex of the freshwater medusaCraspedacusta sowerbii Lankester (Hydrozoa, Limnomedusae). J. Ultrastruct. Res. 1985, 90, 89-104. [CrossRef]

9. Pyo, M.-J.; Lee, H.; Bae, S.K.; Heo, Y.; Choudhary, I.; Yoon, W.D.; Kang, C.; Kim, E. Modulation of jellyfish nematocyst discharges and management of human skin stings in Nemopilema nomurai and Carybdea mora. Toxicon 2016, 109, 26-32. [CrossRef]

10. Burnett, J.W.; Calton, G.J. Venomous pelagic coelenterates: Chemistry, toxicology, immunology and treatment of their stings. Toxicon 1987, 25, 581-602. [CrossRef]

11. Drury, J.; Noonan, J.; Pollock, J.; Reid, W.H. Jelly fish sting with serious hand complications. Injury 1980, 12, 66-68. [CrossRef]

12. Nimorakiotakis, B.; Winkel, K. Marine envenomations: Part 1-jellyfish. Aust. Fam. Phys. 2003, 32, 969.

13. Tibballs, J. Australian venomous jellyfish, envenomation syndromes, toxins and therapy. Toxicon 2006, 48, 830-859. [CrossRef]

14. Brinkman, D.L.; Aziz, A.; Loukas, A.; Potriquet, J.; Seymour, J.; Mulvenna, J. Venom proteome of the box jellyfish Chironex fleckeri. PLoS ONE 2012, 7, e47866. [CrossRef]

15. Brinkman, D.L.; Jia, X.; Potriquet, J.; Kumar, D.; Dash, D.; Kvaskoff, D.; Mulvenna, J. Transcriptome and venom proteome of the box jellyfish Chironex fleckeri. BMC Genom. 2015, 16, 407. [CrossRef]

16. Thaikruea, L.; Siriariyaporn, P. Severe Dermatonecrotic Toxin and Wound Complications Associated With Box Jellyfish Stings 2008-2013. J. Wound Ostomy Cont. Nurs. Off. Publ. Wound Ostomy Cont. Nurses Soc. 2015, 42, 599-604. [CrossRef] [PubMed]

17. Silva-de-França, F.; Villas-Boas, I.M.; Serrano, S.M.T.; Cogliati, B.; Chudzinski, S.A.A.; Lopes, P.H.; Kitano, E.S.; Okamoto, C.K.; Tambourgi, D.V. Naja annulifera Snake: New insights into the venom components and pathogenesis of envenomation. PLoS Negl. Trop. Dis. 2019, 13, e0007017. [CrossRef]

18. Blaylock, R.S. Antibacterial properties of KwaZulu natal snake venoms. Toxicon 2000, 38, 1529-1534. [CrossRef]

19. Hornbeak, K.B.; Auerbach, P.S. Marine Envenomation. Emerg. Med. Clin. N. Am. 2017, 35, 321-337. [CrossRef] [PubMed]

20. Rossetto, A.L.; de Macedo Mora, J.; Haddad Junior, V. Sea urchin granuloma. Rev. Inst. Med. Trop. Sao Paulo 2006, 48, 303-306. [CrossRef]

21. Rojas-Azofeifa, D.; Sasa, M.; Lomonte, B.; Diego-García, E.; Ortiz, N.; Bonilla, F.; Murillo, R.; Tytgat, J.; Díaz, C. Biochemical characterization of the venom of Central American scorpion Didymocentrus krausi Francke, 1978 (Diplocentridae) and its toxic effects in vivo and in vitro. Comp. Biochem. Physiol. Toxicol. Pharmacol. CBP 2019, 217, 54-67. [CrossRef]

22. Pelin, M.; Zanette, C.; De Bortoli, M.; Sosa, S.; Loggia, R.D.; Tubaro, A.; Florio, C. Effects of the marine toxin palytoxin on human skin keratinocytes: Role of ionic imbalance. Toxicology 2011, 282, 30-38. [CrossRef] [PubMed]

23. Kang, C.; Jin, Y.B.; Kwak, J.; Jung, H.; Yoon, W.D.; Yoon, T.-J.; Kim, J.-S.; Kim, E. Protective effect of tetracycline against dermal toxicity induced by Jellyfish venom. PLoS ONE 2013, 8, e57658. [CrossRef] [PubMed]

24. Hwang, D.H.; Lee, H.; Choudhary, I.; Kang, C.; Chae, J.; Kim, E. Protective effect of epigallocatechin-3-gallate (EGCG) on toxic metalloproteinases-mediated skin damage induced by Scyphozoan jellyfish envenomation. Sci. Rep. 2020, 10, 18644. [CrossRef]

25. Choudhary, I.; Hwang, D.H.; Lee, H.; Yoon, W.D.; Chae, J.; Han, C.H.; Yum, S.; Kang, C.; Kim, E. Proteomic Analysis of Novel Components of Nemopilema nomurai Jellyfish Venom: Deciphering the Mode of Action. Toxins 2019, 11, 153. [CrossRef]

26. Senff-Ribeiro, A.; Henrique da Silva, P.; Chaim, O.M.; Gremski, L.H.; Paludo, K.S.; Bertoni da Silveira, R.; Gremski, W.; Mangili, O.C.; Veiga, S.S. Biotechnological applications of brown spider (Loxosceles genus) venom toxins. Biotechnol. Adv. 2008, 26, 210-218. [CrossRef]

27. da Silveira, R.B.; Chaim, O.M.; Mangili, O.C.; Gremski, W.; Dietrich, C.P.; Nader, H.B.; Veiga, S.S. Hyaluronidases in Loxosceles intermedia (Brown spider) venom are endo-beta-N-acetyl-d-hexosaminidases hydrolases. Toxicon Off. J. Int. Soc. Toxinol. 2007, 49, 758-768. [CrossRef]

28. Ombati, R.; Wang, Y.; Du, C.; Lu, X.; Li, B.; Nyachieo, A.; Li, Y.; Yang, S.; Lai, R. A membrane disrupting toxin from wasp venom underlies the molecular mechanism of tissue damage. Toxicon Off. J. Int. Soc. Toxinol. 2018, 148, 56-63. [CrossRef] [PubMed]

29. Xiao, W.; Goswami, P.C. Down-regulation of peroxisome proliferator activated receptor $\gamma$ coactivator $1 \alpha$ induces oxidative stress and toxicity of 1-(4-Chlorophenyl)-benzo-2,5-quinone in HaCaT human keratinocytes. Toxicol. In Vitro. Int. J. Publ. Assoc. Bibra 2015, 29, 1332-1338. [CrossRef] 
30. Zanetti, M.; Braghetta, P.; Sabatelli, P.; Mura, I.; Doliana, R.; Colombatti, A.; Volpin, D.; Bonaldo, P.; Bressan, G.M. EMILIN-1 deficiency induces elastogenesis and vascular cell defects. Mol. Cell. Biol. 2004, 24, 638-650. [CrossRef]

31. Nakatomi, Y.; Tsuruga, E.; Nakashima, K.; Sawa, Y.; Ishikawa, H. EMILIN-1 regulates the amount of oxytalan fiber formation in periodontal ligaments in vitro. Connect. Tissue Res. 2011, 52, 30-35. [CrossRef] [PubMed]

32. Doliana, R.; Mongiat, M.; Bucciotti, F.; Giacomello, E.; Deutzmann, R.; Volpin, D.; Bressan, G.M.; Colombatti, A. EMILIN, a component of the elastic fiber and a new member of the C1q/tumor necrosis factor superfamily of proteins. J. Biol. Chem. 1999, 274, 16773-16781. [CrossRef] [PubMed]

33. Spessotto, P.; Cervi, M.; Mucignat, M.T.; Mungiguerra, G.; Sartoretto, I.; Doliana, R.; Colombatti, A. beta 1 Integrin-dependent cell adhesion to EMILIN-1 is mediated by the gC1q domain. J. Biol. Chem. 2003, 278, 6160-6167. [CrossRef]

34. Bressan, G.M.; Daga-Gordini, D.; Colombatti, A.; Castellani, I.; Marigo, V.; Volpin, D. Emilin, a component of elastic fibers preferentially located at the elastin-microfibrils interface. J. Cell Biol. 1993, 121, 201-212. [CrossRef]

35. Vanhoutteghem, A.; Delhomme, B.; Hervé, F.; Nondier, I.; Petit, J.M.; Araki, M.; Araki, K.; Djian, P. The importance of basonuclin 2 in adult mice and its relation to basonuclin 1. Mech. Dev. 2016, 140, 53-73. [CrossRef] [PubMed]

36. Romano, R.A.; Li, H.; Tummala, R.; Maul, R.; Sinha, S. Identification of Basonuclin2, a DNA-binding zinc-finger protein expressed in germ tissues and skin keratinocytes. Genomics 2004, 83, 821-833. [CrossRef]

37. Tseng, H.; Green, H. Association of basonuclin with ability of keratinocytes to multiply and with absence of terminal differentiation. J. Cell Biol. 1994, 126, 495-506. [CrossRef]

38. Matsuzaki, K.; Inoue, H.; Kumagai, N. Re-epithelialisation and the possible involvement of the transcription factor, basonuclin. Int. Wound J. 2004, 1, 135-140. [CrossRef] [PubMed]

39. Bigas, J.; Sevilla, L.M.; Carceller, E.; Boix, J.; Pérez, P. Epidermal glucocorticoid and mineralocorticoid receptors act cooperatively to regulate epidermal development and counteract skin inflammation. Cell Death Dis. 2018, 9, 588. [CrossRef]

40. Lesovaya, E.; Agarwal, S.; Readhead, B.; Vinokour, E.; Baida, G.; Bhalla, P.; Kirsanov, K.; Yakubovskaya, M.; Platanias, L.C.; Dudley, J.T.; et al. Rapamycin Modulates Glucocorticoid Receptor Function, Blocks Atrophogene REDD1, and Protects Skin from Steroid Atrophy. J. Investig. Dermatol. 2018, 138, 1935-1944. [CrossRef]

41. Reichrath, J. Ancient friends, revisited: New aspects on the important role of nuclear receptor signalling for skin physiology and for the treatment of skin diseases. Derm. Endocrinol. 2011, 3, 121-124. [CrossRef]

42. Pérez, P. Glucocorticoid receptors, epidermal homeostasis and hair follicle differentiation. Derm. Endocrinol. 2011, 3, 166-174. [CrossRef]

43. Sevilla, L.M.; Latorre, V.; Sanchis, A.; Pérez, P. Epidermal inactivation of the glucocorticoid receptor triggers skin barrier defects and cutaneous inflammation. J. Investig. Dermatol. 2013, 133, 361-370. [CrossRef]

44. Rossignol, P.; Ho-Tin-Noé, B.; Vranckx, R.; Bouton, M.C.; Meilhac, O.; Lijnen, H.R.; Guillin, M.C.; Michel, J.B.; Anglés-Cano, E. Protease nexin-1 inhibits plasminogen activation-induced apoptosis of adherent cells. J. Biol. Chem. 2004, $279,10346-10356$. [CrossRef] [PubMed]

45. Sulniute, R.; Shen, Y.; Guo, Y.Z.; Fallah, M.; Ahlskog, N.; Ny, L.; Rakhimova, O.; Broden, J.; Boija, H.; Moghaddam, A.; et al. Plasminogen is a critical regulator of cutaneous wound healing. Thromb. Haemost. 2016, 115, 1001-1009. [CrossRef] [PubMed]

46. Cho, S.H.; Tam, S.W.; Demissie-Sanders, S.; Filler, S.A.; Oh, C.K. Production of plasminogen activator inhibitor-1 by human mast cells and its possible role in asthma. J. Immunol. 2000, 165, 3154-3161. [CrossRef] [PubMed]

47. Weckroth, M.; Vaheri, A.; Virolainen, S.; Saarialho-Kere, U.; Jahkola, T.; Sirén, V. Epithelial tissue-type plasminogen activator expression, unlike that of urokinase, its receptor, and plasminogen activator inhibitor-1, is increased in chronic venous ulcers. Br. J. Dermatol. 2004, 151, 1189-1196. [CrossRef]

48. Le Clainche, C.; Dwivedi, S.P.; Didry, D.; Carlier, M.F. Vinculin is a dually regulated actin filament barbed end-capping and side-binding protein. J. Biol. Chem. 2010, 285, 23420-23432. [CrossRef]

49. von Essen, M.; Rahikainen, R.; Oksala, N.; Raitoharju, E.; Seppälä, I.; Mennander, A.; Sioris, T.; Kholová, I.; Klopp, N.; Illig, T.; et al. Talin and vinculin are downregulated in atherosclerotic plaque; Tampere Vascular Study. Atherosclerosis 2016, 255 , 43-53. [CrossRef]

50. Ezratty, E.J.; Partridge, M.A.; Gundersen, G.G. Microtubule-induced focal adhesion disassembly is mediated by dynamin and focal adhesion kinase. Nat. Cell Biol. 2005, 7, 581-590. [CrossRef] [PubMed]

51. Choi, C.W.; Kim, Y.H.; Sohn, J.H.; Lee, H.; Kim, W.S. Focal adhesion kinase and Src expression in premalignant and malignant skin lesions. Exp. Dermatol. 2015, 24, 361-364. [CrossRef]

52. Xia, H.; Nho, R.S.; Kahm, J.; Kleidon, J.; Henke, C.A. Focal adhesion kinase is upstream of phosphatidylinositol 3-kinase/Akt in regulating fibroblast survival in response to contraction of type I collagen matrices via a beta 1 integrin viability signaling pathway. J. Biol. Chem. 2004, 279, 33024-33034. [CrossRef]

53. Shiwen, X.; Stratton, R.; Nikitorowicz-Buniak, J.; Ahmed-Abdi, B.; Ponticos, M.; Denton, C.; Abraham, D.; Takahashi, A.; Suki, B.; Layne, M.D.; et al. A Role of Myocardin Related Transcription Factor-A (MRTF-A) in Scleroderma Related Fibrosis. PLoS ONE 2015, 10, e0126015. [CrossRef]

54. Haak, A.J.; Tsou, P.S.; Amin, M.A.; Ruth, J.H.; Campbell, P.; Fox, D.A.; Khanna, D.; Larsen, S.D.; Neubig, R.R. Targeting the myofibroblast genetic switch: Inhibitors of myocardin-related transcription factor/serum response factor-regulated gene transcription prevent fibrosis in a murine model of skin injury. J. Pharmacol. Exp. Ther. 2014, 349, 480-486. [CrossRef] 
55. Velasquez, L.S.; Sutherland, L.B.; Liu, Z.; Grinnell, F.; Kamm, K.E.; Schneider, J.W.; Olson, E.N.; Small, E.M. Activation of MRTF-A-dependent gene expression with a small molecule promotes myofibroblast differentiation and wound healing. Proc. Natl. Acad. Sci. USA 2013, 110, 16850-16855. [CrossRef] [PubMed]

56. Baker, B.S. The role of microorganisms in atopic dermatitis. Clin. Exp. Immunol. 2006, 144, 1-9. [CrossRef]

57. Begon, E.; Michel, L.; Flageul, B.; Beaudoin, I.; Jean-Louis, F.; Bachelez, H.; Dubertret, L.; Musette, P. Expression, subcellular localization and cytokinic modulation of Toll-like receptors (TLRs) in normal human keratinocytes: TLR2 up-regulation in psoriatic skin. Eur. J. Dermatol. EJD 2007, 17, 497-506. [CrossRef] [PubMed]

58. Jin, S.E.; Lim, H.S.; Kim, Y.; Seo, C.S.; Yoo, S.R.; Shin, H.K.; Jeong, S.J. Traditional Herbal Formula Banhasasim-tang Exerts Anti-Inflammatory Effects in RAW 264.7 Macrophages and HaCaT Keratinocytes. Evid. Based Complement. Altern. Med. ECAM 2015, 2015, 728380. [CrossRef]

59. Muthusamy, V.; Piva, T.J. The UV response of the skin: A review of the MAPK, NFkappaB and TNFalpha signal transduction pathways. Arch. Dermatol. Res. 2010, 302, 5-17. [CrossRef]

60. Abdou, A.G.; Elwahed, M.G.; Serag El-Dien, M.M.; Eldien, D.S. Immunohistochemical expression of MCM2 in nonmelanoma epithelial skin cancers. Am. J. Dermatopathol. 2014, 36, 959-964. [CrossRef] [PubMed]

61. Gerbaud, P.; Guibourdenche, J.; Jarray, R.; Conti, M.; Palmic, P.; Leclerc-Mercier, S.; Bruneau, J.; Hermine, O.; Lepelletier, Y.; Raynaud, F. APN/CD13 is over-expressed by Psoriatic fibroblasts and is modulated by CGRP and IL-4 but not by retinoic acid treatment. J. Cell. Physiol. 2018, 233, 958-967. [CrossRef] [PubMed]

62. Kunii, R.; Nemoto, E.; Kanaya, S.; Tsubahara, T.; Shimauchi, H. Expression of CD13/aminopeptidase N on human gingival fibroblasts and up-regulation upon stimulation with interleukin-4 and interleukin-13. J. Periodontal Res. 2005, 40, 138-146. [CrossRef]

63. Sorrell, J.M.; Brinon, L.; Baber, M.A.; Caplan, A.I. Cytokines and glucocorticoids differentially regulate APN/CD13 and DPPIV/CD26 enzyme activities in cultured human dermal fibroblasts. Arch. Dermatol. Res. 2003, 295, 160-168. [CrossRef] [PubMed]

64. Russell, J.S.; Chi, H.; Lantry, L.E.; Stephens, R.E.; Ward, P.E. Substance P and neurokinin A metabolism by cultured human skeletal muscle myocytes and fibroblasts. Peptides 1996, 17, 1397-1403. [CrossRef]

65. Bloom, D.A.; Burnett, J.W.; Alderslade, P. Partial purification of box jellyfish (Chironex fleckeri) nematocyst venom isolated at the beachside. Toxicon Off. J. Int. Soc. Toxinol. 1998, 36, 1075-1085. [CrossRef]

66. Carrette, T.; Seymour, J. A rapid and repeatable method for venom extraction from cubozoan nematocysts. Toxicon Off. J. Int. Soc. Toxinol. 2004, 44, 135-139. [CrossRef] [PubMed]

67. Bradford, M.M. A rapid and sensitive method for the quantitation of microgram quantities of protein utilizing the principle of protein-dye binding. Anal. Biochem. 1976, 72, 248-254. [CrossRef]

68. Averbukh, L.A. Study using the probit-analysis method of the process of increasing resistance to dipin and bruneomycin in Fisher L-5178 lymphadenosis cells in experiments on animals. Antibiotiki 1976, 21, 169-174. [PubMed]

69. Mortz, E.; Krogh, T.N.; Vorum, H.; Görg, A. Improved silver staining protocols for high sensitivity protein identification using matrix-assisted laser desorption/ionization-time of flight analysis. Proteomics 2001, 1, 1359-1363. [CrossRef]

70. Shevchenko, A.; Jensen, O.N.; Podtelejnikov, A.V.; Sagliocco, F.; Wilm, M.; Vorm, O.; Mortensen, P.; Shevchenko, A.; Boucherie, H.; Mann, M. Linking genome and proteome by mass spectrometry: Large-scale identification of yeast proteins from two dimensional gels. Proc. Natl. Acad. Sci. USA 1996, 93, 14440-14445. [CrossRef] 